\section{UKCPR}

University of Kentucky

Center for

Poverty Research

\section{Discussion Paper Series}

DP 2014-09

ISSN: 1936-9379

\title{
Income, Program Participation, Poverty, and Financial Vulnerability: Research and Data Needs
}

\author{
James P. Ziliak \\ Center for Poverty Research \\ Department of Economics \\ University of Kentucky
}

Preferred citation

Ziliak, J., Income, Program Participation, Poverty, and Financial Vulnerability: Research and Data Needs. University of Kentucky Center for Poverty Research Discussion Paper Series, DP2014-09. Retrieved [Date] from http://www.ukcpr.org/Publications/DP2014-09.pdf.

\section{Author correspondence}

James P. Ziliak, University of Kentucky, Center for Poverty Research, Mathews Building, Suite 300, Lexington, KY 40506-0047; Email: jziliak@email.uky.edu; Phone: (859)257-6902 


\title{
Income, Program Participation, Poverty, and Financial Vulnerability: Research and Data Needs
}

\author{
James P. Ziliak* \\ Center for Poverty Research \\ Department of Economics \\ University of Kentucky
}

\begin{abstract}
Prepared for the National Science Foundation Conference
Assessing the Need for a New Nationally

Representative Household Panel Survey in the United States

June 5-6, 2014
\end{abstract}

* Address correspondence to James P. Ziliak, University of Kentucky, Center for Poverty Research, Mathews Building Suite 300, Lexington, KY 40506-0047. I thank Lewis Warren for research assistance on the preparation of this manuscript, and the helpful comments of Charlie Brown, David Grusky, Helen Levy, Shelly Lundberg, Robert Moffitt, Bob Schoeni, and Lowell Taylor. All errors are my own. 


\begin{abstract}
The aim of this paper is to assess the adequacy of the data infrastructure in the United States to meet future research and policy evaluation needs as it pertains to income, program participation, poverty, and financial vulnerability. I first discuss some major research themes that are likely to dominate policy and scientific discussions in the coming decade. This list includes research on the long-term consequences of income inequality and mobility, issues of transfer-program participation and intergenerational dependence, challenges with poverty measurement and poverty persistence, and material deprivation. I then summarize what information we currently collect in the U.S. that is used to address these issues, with particular focus on ten national panel datasets that cover these domains and continue to be fielded by the various federal agencies. Included in this section is a discussion of challenges posed by rising income nonresponse and underreporting in many panel surveys. I then conclude with a discussion of how the current panel surveys can be improved to address growing need for social science research on inequality, poverty, and material well being.
\end{abstract}


The availability of household panel data over the past four decades provided the means for a great leap forward in social science research on scores of issues related to income, transfer program participation, poverty, and financial vulnerability in the United States. This long list includes, among others, research on the entry into and exit out of poverty and/or transferprogram participation (Bane and Ellwood 1986; Katz and Meyer 1990; Blank and Ruggles 1996; Stevens 1999); intergenerational transmission of economic status (Duncan, Hill, and Hoffman 1988; Solon 1992); earnings dynamics (Lillard and Willis 1978; MaCurdy 1982; Abowd and Card 1989; Gottschalk and Moffitt 1994; Meghir and Pistaferri 2004); the wage returns to education, experience, industry, union status, job safety, and job training (Chamberlain 1978; Brown 1980; Hausman and Taylor 1981; Freeman 1984; Card 1986; Lalonde 1986; Altonji and Shakotko 1987; Krueger and Summers 1988; Heckman, Ichimura, and Todd 1997; Keane and Wolpin 1997; Kniesner, et al. 2012); the income-smoothing benefits of extended families, taxes, and transfers (Hall and Mishkin 1982; Cochrane 1991; Hayashi, Altonji, and Kotlikoff 1996; Dynarski and Gruber 1997; Kniesner and Ziliak 2002; Blundell, Pistaferri, and Preston 2008); and more recently, the long-term effects of early childhood interventions (Garces, Thomas, and Currie 2002; Heckman, Stixrud, and Urzua 2006; Hoynes, Schanzenbach, and Almond 2013). Much of this research included methodological innovations on the econometrics of panel data, along with crucial insights on the role of public policies in shaping household decision making. Are current data sufficient to foster the next 40 years of social science research? Or is it time for the nation to embark on a new data collection enterprise?

The aim of this paper is to assess the adequacy of the data infrastructure in the U.S. to meet future research and policy evaluation needs as it pertains to income, program participation, poverty, and financial vulnerability. Any assessment of data must first be motivated by the 
questions being posed, and thus the paper opens with a discussion of some major research themes that are likely to dominate policy and scientific discussions in the coming decade. By no means is the list intended to be exhaustive, and in part reflects personal research biases. Attention is necessarily confined to those topics best addressed with longitudinal data, though key (repeated) cross-sectional datasets are referenced to the extent that they provide relevant benchmarks to anchor a possible new panel. This is then followed with an accounting of current longitudinal surveys. Included here is a discussion of measurement issues, both the construction of current and potentially new measures of income, poverty, and vulnerability, as well as data quality such as survey nonresponse and underreporting. The final section contains a discussion of whether a new longitudinal panel is needed in the United States in the domain of income, poverty, and financial hardship. The prospects of linking administrative data with survey data are also explored. Indeed, one of the remarkable feats of the first wave of longitudinal research was that it was conducted during the early stages of computing architecture. New data storage and processing power make feasible the analysis of massive data sets, which characterizes many administrative data sources such as tax records or welfare programs.

\section{What Do We Need to Know about Income, Program Participation, Poverty, and Financial Vulnerability?}

\section{A. Consequences of Income Inequality}

With little risk of hyperbole, the defining economic trend of our time is rising income inequality. Figure 1 depicts trends in household income shares by quintile of the distribution from the Annual Social and Economic Supplement of the Current Population Survey (CPS). ${ }^{1}$ The figure shows that over the past four decades the share of income accruing to the top fifth of

\footnotetext{
${ }^{1}$ Data obtained from Table H-2 at http://www.census.gov/hhes/www/income/data/historical/household/
} 
Figure 1. Trends in Household Income Shares

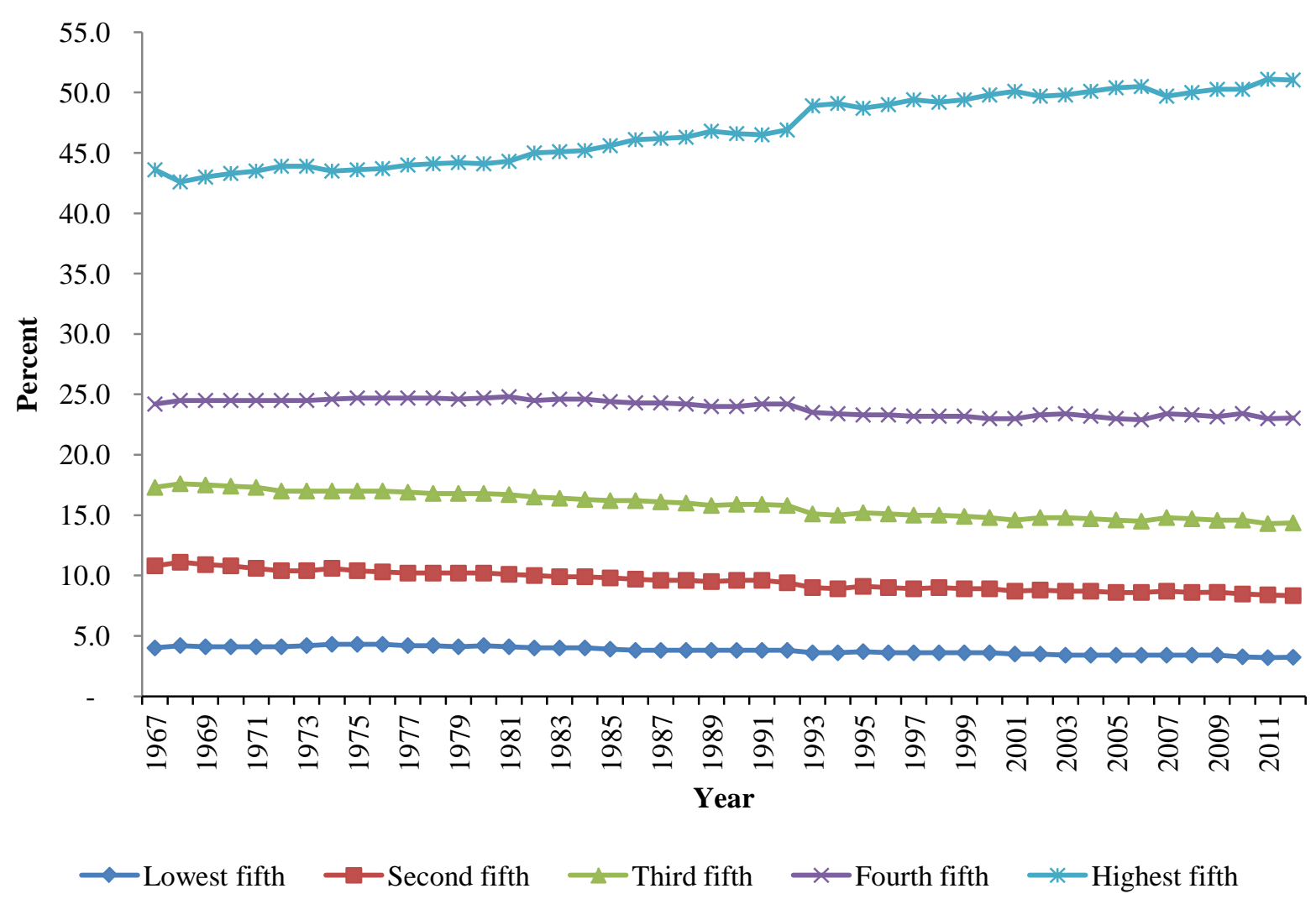

the income distribution has been increasing at the expense of the bottom four-fifths, rising from 43.6 percent of total income in 1967 to 51 percent in 2012. The declines in shares cut across both the lower and middle income classes, resulting in a "polarization" of incomes (Autor, Katz, and Kearney 2008).

Figure 2 presents a more stark portrait of what is happening at the top of the income distribution, utilizing tax return data from Piketty and Saez (2003) updated to the 2012 tax year. ${ }^{2}$ The figure presents trends in the share of income among the top 1\%, both with and without capital gains income. The share at the top reached just over 20 percent of all income in the late 1920s, and then there was a four decade long decline down to about 8 percent of income in the

\footnotetext{
${ }^{2}$ Data obtained from http://elsa.berkeley.edu/users/saez/TabFig2012prel.xls
} 


\section{Figure 2. Trends in Income Shares of Top 1\%}

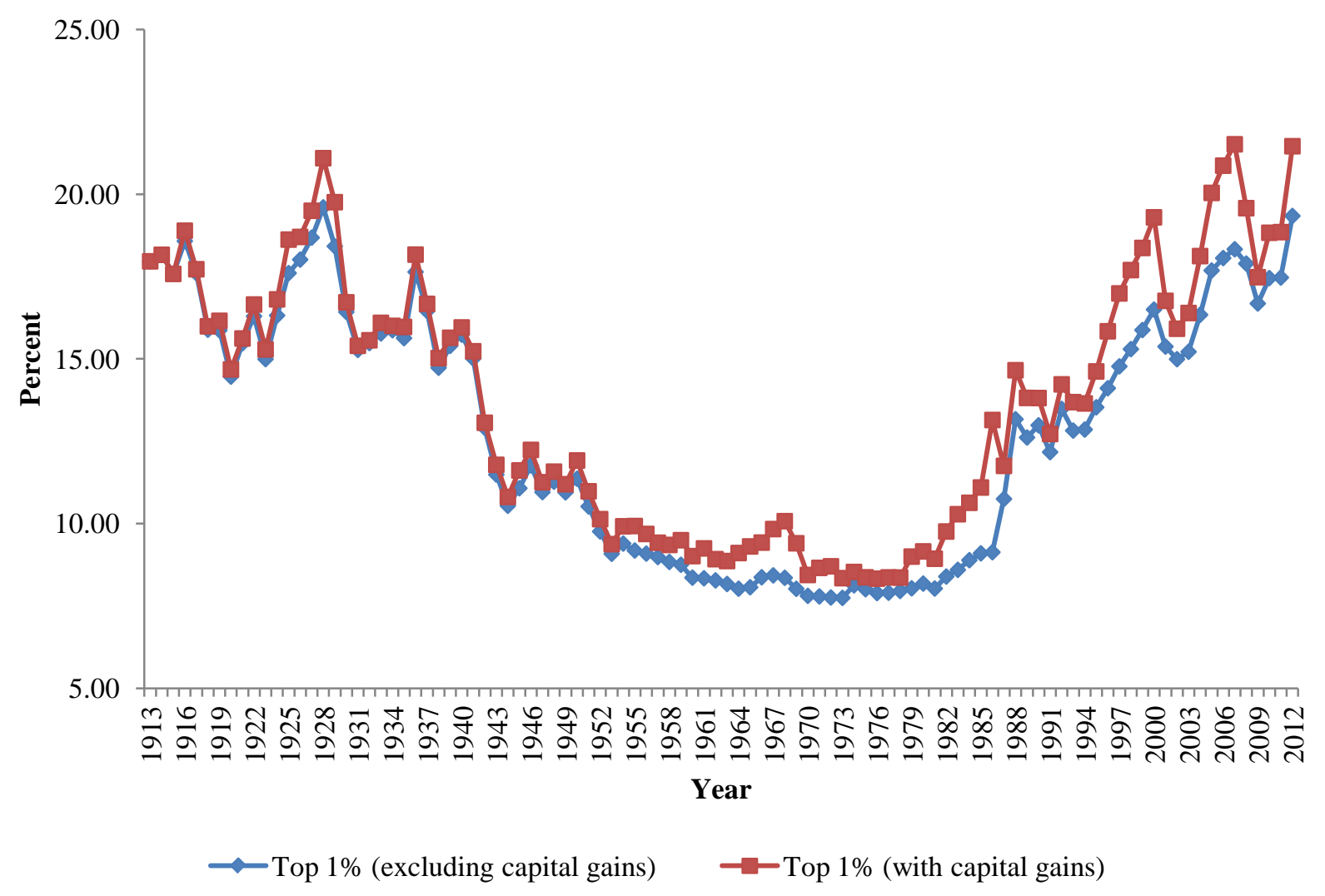

mid 1970s. Since that time the top $1 \%$ share of income has climbed back up to once again exceed 20 percent. A distinguishing feature of the trends in Figure 2 is that the decades in both the early and latter part of the sample period were characterized by significant volatility at the top, compared to relative stability in the middle decades of the $20^{\text {th }}$ century.

There have been scores of studies documenting trends in income inequality and volatility, as well as its causes, and this remains an active area of inquiry. ${ }^{3}$ One of the key distinctions in the most recent work on this topic is whether it is based on household survey data (e.g. Burkhauser, et al. 2012), on tax return data (e.g. Piketty and Saez 2003), or some combination of

\footnotetext{
${ }^{3}$ For examples of income inequality and volatility research over the last decade see Haider 2001; Piketty and Saez 2003; Lemieux 2006; Hacker 2006; Western 2007; Autor, et al. 2008; Parker and Vissing-Jorgenson 2010; Dahl, Deleire, and Schwabish 2011; Ziliak, Hardy, and Bollinger 2011; Burkhauser, et al. 2012; Dynan, Elmendorf, and Sichel 2012; Gottschalk and Moffitt 2012; Weeden and Grusky 2012; Alvaredo, et al. 2013; Attanasio, Hurst, and Pistaferri Forthcoming.
} 
survey and administrative data (Dahl, et al. 2011). For the better part of three decades, repeated cross section samples from the CPS have been used to document inequality trends owing to the relatively large and national representativeness of the survey. Piketty and Saez (2003) were innovative in their use of tax return data for inequality research, arguing that it is advantageous both because it is possible to go back much further in time than any household survey (compare Figure 2 to Figure 1 above) and for the better coverage of incomes at the top of the distribution. A challenge facing all household surveys is capturing incomes at the top of the distribution as these families are less likely to participate in surveys. Moreover, in a bid to preserve respondent confidentiality, inequality researchers face the additional challenge of income top-coding in public use data. This has the effect of masking what is happening in the upper tail of the distribution, which, as Piketty and Saez (2003) highlight, misses the main story over the last few decades. A careful study by Burkhauser, et al. (2012) shows that versions of the CPS held internally at the Census Bureau (which are also top-coded, but at a higher level) track inequality trends in tax return data, but come close to matching the levels only after making adjustments to the data above the top code. For example, in a follow-up paper, Armour, Burkhauser, and Larrimore (2014) show that once one corrects for top coding by incorporating a cell-mean series based on the Pareto distribution inequality levels and trends from the CPS track administrative data. As inequality trends will continue to be an important barometer of the economy in the coming years, in the next section I discuss in greater detail issues of survey nonresponse at both the top and bottom of the distribution, and the implications for inequality research.

In contradistinction to the voluminous literature on trends in and causes of inequality, there has been much less research on the potential long-term consequences of inequality. ${ }^{4}$ Most

\footnotetext{
${ }^{4}$ There has, however, been many studies on the long-term consequences of growing up in poverty. See, for example, McLanahan and Sandefur (1994) and Duncan and Brooks-Gunn (1999).
} 
inequality research is based on income snapshots at a point-in-time, and inequality across the lifecourse may be less severe, unless part of rising inequality owes to reduced upward mobility (or increased downward mobility) across the distribution. ${ }^{5}$ In this case, we need to move beyond inequality to income mobility (Corak 2013; Kenworthy 2013). Does cross sectional inequality reduce upward mobility? And if so, is reduced mobility exacerbating lifetime inequality in incomes and financial well being? To answer these questions it is necessary to follow individuals and families over time. For example, new research on the geography of inequality by Chetty, et al. (2014a) using earnings from longitudinal tax return data suggests that children growing up in more unequal communities experience less upward mobility. This work, along with their compendium piece on trends in mobility (Chetty, et al. 2014b), is very impressive in part owing to the scale of the tax data by fine geographic regions. Indeed, Grusky and Cumberworth (2010) make a case that going forward intergenerational mobility research would be best served utilizing administrative tax records, or at least for measuring trends, in part because of the challenges of estimating integenerational correlations with precision in currently available panel surveys (Aaronson and Mazumder 2008; Lee and Solon 2009).

However, there are several reasons why tax data should be viewed as a complement and not a substitute for longitudinal survey data for research on the causal mechanisms underlying inequality and mobility. First, demographics, especially household family structure, race, and education attainment are not recorded in U.S. tax data. This means it is not possible to identify resource sharing among cohabiting partners, multigenerational families, and multi-family households, or differences in outcomes by race and ethnicity. It also means that it is not possible to relate skill formation with economic opportunity. Recent work by Heckman, Stixrud, and

\footnotetext{
${ }^{5}$ Unlike inequality, research on earnings and income volatility is the near exclusive domain of longitudinal surveys, especially the Panel Study of Income Dynamics (Gottschalk and Moffitt 1994, 2012; Haider 2001; Meghir and Pistaferri 2004; Hacker 2006; Dynan, et al. 2012).
} 
Urzua (2006) points to the important role of early cognitive and noncognitive skill formation on later-life earnings, while Greenwood, et al. (2014) emphasize how the rise in assortative mating, as measured by adults with similar education levels, leads to higher inequality, and thus the prospect for reduced intergenerational mobility. Second, there is evidence that tax data tends to understate earnings at the bottom of the distribution (Hokayem, et al. 2014), and incomes more generally. Some earnings are "under the table" and not reported to tax and welfare authorities (Edin and Lein 1997; Venkatesh 2006), and many sources of income such as cash and in-kind welfare payments are not taxable and thus not available in tax panels. Third, tax data are not in the public domain and thus exclusive reliance will relegate this research to those in government agencies or fortunate enough to gain access. However, this recent work does point to the need to enhance linked tax, transfer, and survey data as discussed below.

\section{B. Program Participation and Intergenerational Dependence}

There has been a dramatic expansion of the social safety net in the U.S. over the past 30 years. Table 1 shows that from 1980 to 2010 real spending on the Earned Income Tax Credit increased nearly 1300 percent, Medicare and Medicaid increased 500 percent or more, spending on Disability Insurance, Unemployment Insurance, and food stamps have each increased over 200 percent, and there was a more than doubling of spending on Social Security retirement (OASI), Supplemental Security Income, and Housing Assistance. The only program exhibiting minimal change in expenditure is AFDC/TANF.

The reasons for this growth in safety net spending vary by program, but generally involve some combination of changing demographics, business cycles, and direct policy reforms (Moffitt and Scholz 2010; Ziliak 2011). For example, the aging of the U.S. population has fueled real growth in Social Security, Medicare, and Medicaid, though the latter two programs also 
Table 1. Trends in Real Spending on Selected Social Insurance and Means-Tested Transfer Programs

\begin{tabular}{|c|c|c|c|c|}
\hline & 1980 & 1990 & 2000 & 2010 \\
\hline \multicolumn{5}{|l|}{ Social Insurance } \\
\hline OASI & 256.3 & 354.0 & 452.2 & 550.4 \\
\hline Medicare & 89.8 & 176.2 & 284.4 & 535.7 \\
\hline Disability Insurance & 37.8 & 39.4 & 70.4 & 130.7 \\
\hline Workers Compensation & 33.2 & 60.6 & 61.2 & 61.3 \\
\hline Unemployment Insurance & 39.3 & 29.0 & 26.8 & 145.9 \\
\hline Veterans Benefits & 35.9 & 28.1 & 32.1 & 54.1 \\
\hline \multicolumn{5}{|l|}{ Means-Tested Transfers } \\
\hline Medicaid & 56.8 & 103.0 & 215.9 & 356.6 \\
\hline Supplemental Security Income & 18.8 & 25.6 & 39.4 & 50.7 \\
\hline AFDC/TANF & 32.7 & 35.1 & 36.3 & 37.7 \\
\hline Food Stamps/SNAP & 21.2 & 24.4 & 21.9 & 71.9 \\
\hline Housing Assistance & 22.2 & 28.7 & 41.9 & 44.4 \\
\hline Earned Income Tax Credit & 4.6 & 11.9 & 41.4 & 64.1 \\
\hline
\end{tabular}

Note: Expenditures are in 2013 dollars based on the personal consumption expenditure deflator.

Sources: 2013 Annual Statistical Supplement to the Social Security Bulletin (OASI and DI from Table 7.A.4; Medicare is the sum of Table 8.A.1 \& 8.A.2; Medicaid from Table 8.E2 (1980 value from the 2000 supplement); SSI from Table 7.A.4; Workers Compensation from Table 9.B1); UI data includes extended benefits and was obtained from https://workforcesecurity.doleta.gov/unemploy/Chartbook/b1.asp; Veterans Benefits for 1980 from Table 518 at https://www.census.gov/prod/2002pubs/01statab/socinsur.pdf; Veterans Benefits for 1990, 2000, 2009 from Table 540 at https://www.census.gov/compendia/statab/2012/tables/12s0540.pdf ; AFDC for 1980 from Table 8-22 of 1996 Green Book at http://www.gpo.gov/fdsys/pkg/GPO-CPRT-104WPRT23609/pdf/GPO-CPRT104WPRT23609-2-8.pdf ; AFDC for 1990 and TANF for 2000 and 2010 from Table 7-2 of 2012 Green Book at http://greenbook.waysandmeans.house.gov/sites/greenbook.waysandmeans.house.gov/files/2012/documents/Table\% 207-2\%20TANF_0.pdf ; Food Stamps/SNAP from http://www.fns.usda.gov/pd/SNAPsummary.htm; Housing Assistance for 1980, 1990, 2000 from Table 15.2 from http://democrats.waysandmeans.house.gov/sites/democrats.waysandmeans.house.gov/files/documents/hap.pdf; Housing Assistance for 2011 from Table A.1 of http://greenbook.waysandmeans.house.gov/sites/greenbook.waysandmeans.house.gov/files/2012/documents/RL418 23_gb.pdf.

experienced supernumerary medical-cost inflation and programmatic expansions (Part D prescription drug benefits in 2004 for Medicare, and both SCHIP and higher income eligibility for Medicaid in the 1990s). The growth in Unemployment Insurance occurred with the Great Recession of 2008 and the subsequent adoption of extended benefits that enabled some workers to receive UI for up to 73 weeks beyond the usual 26 weeks. The rise in disability reflects changes in the implementation of program rules and a greater fraction of the population applying for benefits. Autor and Duggan (2006) argue the latter stems from a secular decline in 
employment and a larger pool of potential workers due to the increase in female labor force participation post 1970 . The growth in the EITC coincided with increases in benefit generosity starting in 1993 along with the 1996 welfare reform that moved many single mothers into work (Meyer and Rosenbaum 2001). Meanwhile, the surge in food stamp spending is almost solely due to the weak labor market since 2000 along with policy liberalization for eligibility (Ganong and Liebman 2013; Ziliak 2013).

Some of these programs have received substantial investigation by the research community, especially the EITC and AFDC/TANF programs, and to a lesser extent, food stamps (Haveman, Danziger, and Plotnick 1981; Moffitt 1992, 2003; Currie 2003; Hotz and Scholz 2003; Blank 2009). Historically this research focused on the determinants of participation and the associated work (dis)incentive effects of the programs, usually in a static, cross-sectional setting. In recent years attention has extended to other outcomes, including marriage, fertility, health, and consumption. Research exploiting longitudinal data traditionally focused on the dynamics of entry and exit onto programs (Hutchens 1981; Bane and Ellwood 1994; Blank and Ruggles 1996; Hoynes 2000; Gittleman 2001), though newer work has also examined the potential of the programs to smooth incomes over time (Dynarski and Gruber 1997; Blundell and Pistaferri 2003; Gundersen and Ziliak 2003; Blundell, et al. 2008). But there has been comparatively much less research on other programs such as Disability Insurance, Supplemental Security Income, Housing Assistance, Workers Compensation, and Veterans Benefits despite expenditures being on par or larger than the more heavily studied programs in the safety net. And research on multiple program participation is rare, including basic research on turnover in programs over time and the business cycle (Weinberg 1985; Blank and Ruggles 1996; Keane and 
Moffitt 1998; Moffitt 2014). These are significant gaps in our knowledge base, and in crucial need of filling.

Another area ripe for new research and ideally suited for longitudinal data is intergenerational transmission of welfare use. In the U.S. intergenerational dependence has with few exceptions referred to the welfare program AFDC (Gottschalk 1990; Pepper 2000; Page 2004). However, to my knowledge there has been no work on whether or not there has been a change in that link after passage of welfare reform, despite one of the stated goals of the TANF program "to end the dependency of needy parents on government benefits ...." ${ }^{6}$ Moreover, there is no research on the transmission of "new" welfare such as the EITC, SNAP, DI, or SSI. Recent work by Dahl, et al. (2013) has used Norwegian administrative data to document a strong intergenerational transmission of disability. Current spending on DI and SSI in the U.S. is in excess of $\$ 180$ billion, and while there are some conjectures in the popular press about disability cultures (e.g. Kristof 2012), no such link has been established in the U.S. Identifying whether such transmission exists seems high priority, not least of which because disability tends to be an absorbing state, i.e., once one qualifies for benefits, exits from the program are highly unlikely.

\section{Poverty Measurement and Poverty Persistence}

Was the War on Poverty won? This has been an oft-raised question recently by scholars, journalists, and policymakers alike on the 50th anniversary of President Johnson's declaration of an “unconditional war on poverty” in January of 1964 (Meyer and Sullivan 2012; Ziliak 2012; Bailey and Danziger 2013; Council of Economic Advisers 2014; House Budget Committee 2014; Lowrey 2014) . To some, the answer to the question is no, quite simply because the poverty rate today stands at 15 percent of the population, which is no different than the rate in 1964. However, a closer look at the data reveals that the safety net has had a significant

\footnotetext{
6 “What is TANF?” U.S. Department of Health and Human Services, http://answers.hhs.gov/questions/4482 .
} 
Figure 3. County Poverty Rates in 1959
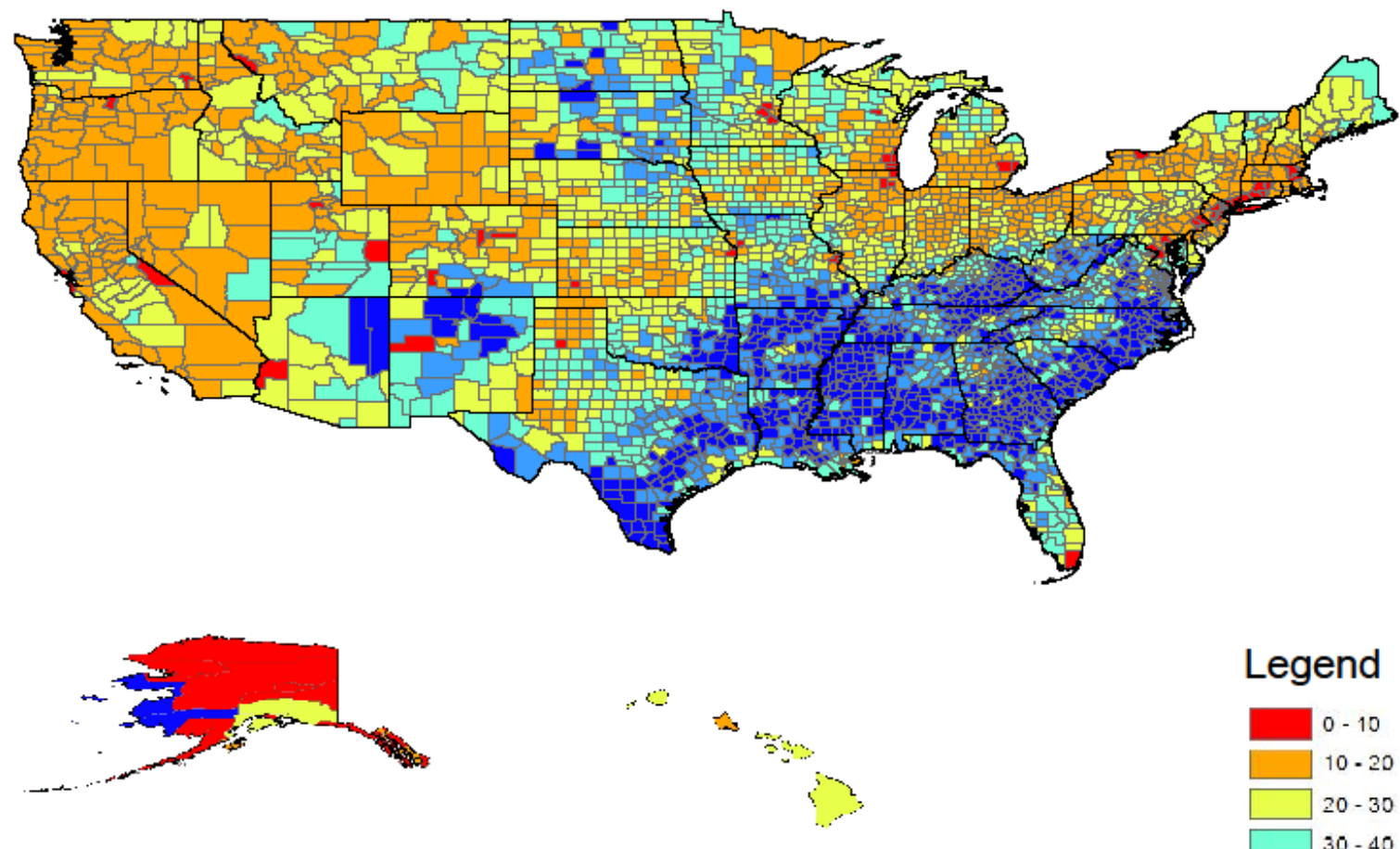

Legend

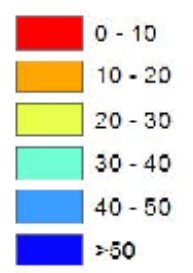

effect on reducing the both rate and depth of poverty in America (Ziliak 2006, 2011; Moffitt and Scholz 2010; Wimer, et al. 2013).

Figure 3 shows poverty rates by county from the 1960 Decennial Census, where poverty rates in excess of 50 percent were the norm in much of the South. By the 2000 Census, however, extreme North-South differences in poverty rates were all but eliminated as seen in Figure 4. Moreover, these poverty rates are based on the official Census Bureau definition of income, which does not include the cash value of in-kind transfers such as food stamps and housing assistance, nor tax credits like the EITC, and does not subtract tax payments. Recent estimates in 
Figure 4. County Poverty Rates in 1999
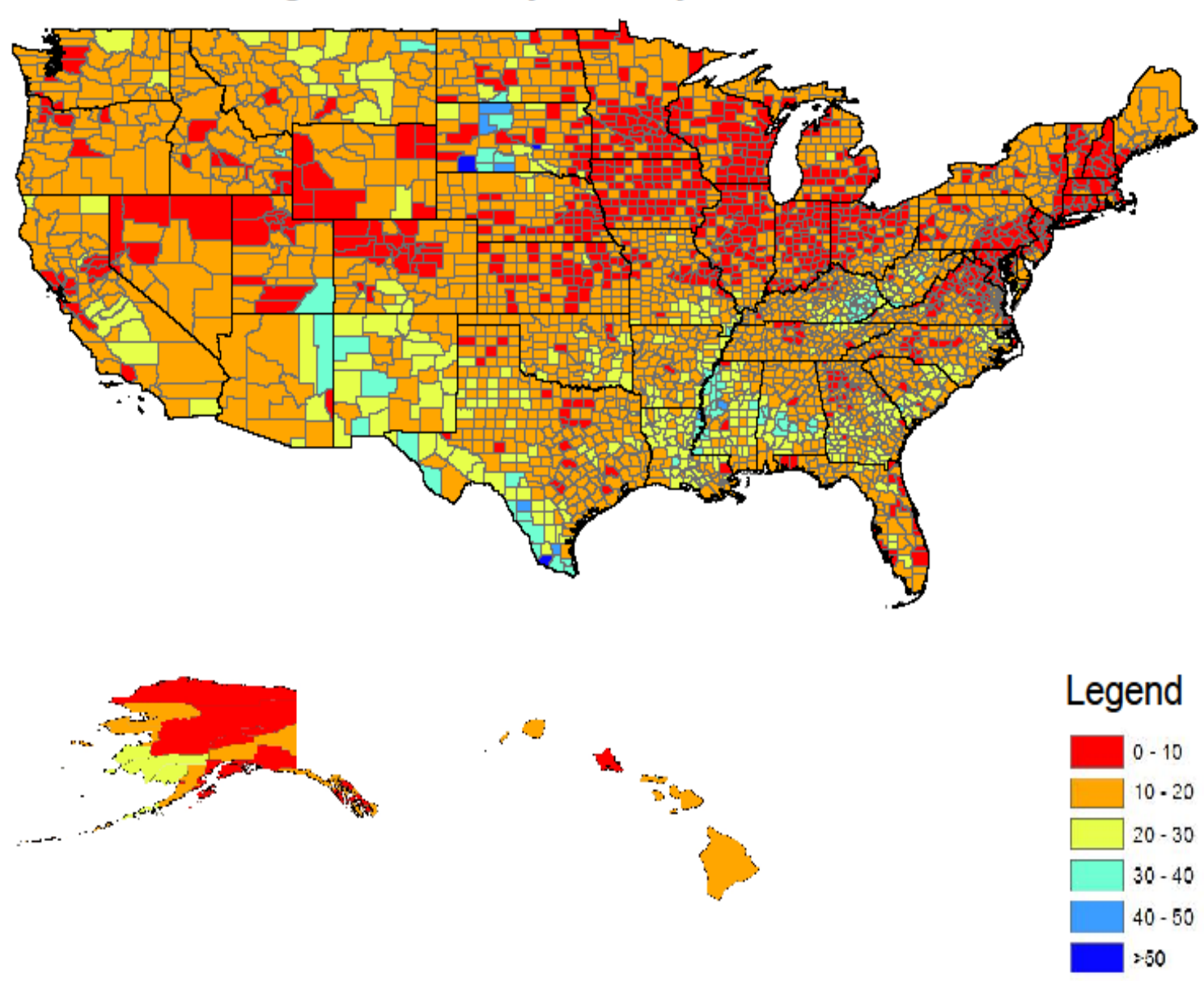

Ziliak (2011) using data from the CPS suggests that these latter adjustments alone reduced the level of poverty by about 16 percent in a typical year over the last decade, and the safety net overall reduced pre-tax and pre-transfer poverty by at least two-thirds. Moffitt and Scholz (2010) reach similar conclusions using data from the SIPP.

Wimer, et al. (2013) go further by backcasting the Census Bureau’s Supplemental Poverty Measure (SPM) to the beginning of the War on Poverty programs in 1967. The SPM, building off the recommendations of a National Academy of Sciences panel recommendation (Citro and Michael 1995), differs in several ways from the current official measure, both in how 
the poverty line is constructed and how resources are defined (Short 2013). The official poverty line is set at three times the level of expenditure necessary to attain the USDA's economy food plan in 1963 and updated annually by changes in the Consumer Price Index. The SPM line, on the other hand, is set at the $33^{\text {rd }}$ percentile of the distribution of spending on food, clothing, shelter, and utilities (and a little extra) based on a five-year moving average of data from the Consumer Expenditure Survey. Moreover, the official line is fixed across the 50 states and District of Columbia; whereas, the SPM line is adjusted for geographic differences in housing prices both within and between states. Thus, the data needed to construct the SPM line are much more extensive. The definition of resources in the official measure includes most forms of realized private income (except capital gains and losses), along with cash transfers from the government. The SPM includes all these factors plus the value of food assistance, housing assistance, and the EITC, less out-of-pocket spending on child care and other work expenses, child support, medical expenses, and tax payments. Wimer, et al. show that the SPM fell from 26 percent in 1967 to 16 percent in 2012, a period when the official rate was little changed, providing compelling descriptive evidence that the wider safety net has reduced poverty over the last 50 years. Collectively, this literature suggests that how one measures poverty has a substantive effect on the evaluation of the safety net; that is, it is crucial to incorporate in-kind transfers and tax credits, and to look at alternative measures of poverty.

Even with the expansion of the safety net, however, poverty rates have remained stubbornly high nationally, and especially so in certain regions of the country. For example, in Figure 4 one sees poverty rates in excess of 20 or 30 percent clustered in five subregionsCentral Appalachia (especially Eastern Kentucky), the Southern Black Belt (the Carolinas to central Mississippi), the Mississippi Delta, the Texas ‘colonias’ (counties on the Rio Grande 
River), and Native American reservations. These areas, while different in terms of geography, culture, and economic specialization, share the common feature of being rural. However, with finer gradation of geographic space, one would also uncover similar patterns of concentrated poverty within certain metropolitan areas (Wilson 1987; Jargowsky 1997; Kneebone, Nadeau, and Berube 2011; Gennetian, et al. 2013).

Concentration of poverty generates concerns over poverty persistence and its underlying causes, and indeed the possible emergence of poverty traps. Traditionally, individuals, and not regions per se, are the unit of analysis for poverty traps. In this vein, Durlauf (2012) defines a poverty trap as a situation where poverty is (i) persistent, (ii) perpetuated across an individual's life or across generations, and (iii) perpetuated by socioeconomic features outside of the individual's control. By construction, research on lifecycle or dynastic poverty requires rich longitudinal data that links not only extended families but also aspects of the local community such as political institutions and other environmental factors. Sawhill (1988, p. 1085) lamented 26 years ago that

"Few researchers have approached the task of analyzing the effects of different variables on the poverty rate in the context of a coherent overall model of the process by which income is generated..... We are swamped with facts about people’s incomes and about the number and composition of people who inhabit the lower tail, but we don't know very much about the process that generates these results.”

Sawhill was actually commenting on the lack of theoretical foundations underlying the income generation process. Perhaps ironically, a decade and a half later Moffitt (2004, p. 75) concluded that "In the literature on social interactions, theory has run considerably ahead of empirical testing, the development of policy interventions that work through social interactions, and the 
evaluation of such interventions.” In other words, theorists implicitly rose to the challenge posed by Sawhill, but empirical researchers, beyond the many works on peer effects in schooling and neighborhood effects, have not made significant strides in estimating models of lifecourse poverty persistence even though transitional matrices of intergenerational income mobility suggest that the odds of being poor as an adult are substantially greater if the person was poor in childhood. The new analysis by Chetty, et al. (2014) on the geography of immobility hints that the local environment is strongly correlated with this outcome, and future empirical research needs to delve deeper into whether causal mechanisms are at work here.

D. Financial Vulnerability and Material Hardship

Some have argued that income poverty overstates the situation facing the poor today because most have access to basic amenities such as air conditioning, automobiles, cell phones, microwave ovens, TVs, VCRs, etc...; in other words, they are not experiencing "material hardship” (Rector 2007). Still others claim that underreporting of transfer income exacerbates income poverty, and that measuring nondurable consumption provides a more accurate portrait of the poverty status of families (Meyer and Sullivan 2012). Both of these critiques raise valid concerns, and suggest that in order to better assess well-being it is necessary to collect and measure other indicators of hardship. Indeed, Mayer and Jencks (1989) argued that measures of material hardship are materially and conceptually distinct from income poverty, and that both measures should be collected regularly. This leads more broadly into calls for a move away from a single poverty index, whether it be income or consumption, to multidimensional measures of poverty (Sen 1993; Bourguignon and Chakravarty 2003; Stiglitz, Sen, Fitoussi 2009).

The focus on basic material goods as argued by Rector (2007), however, overlooks other potential dimensions of financial and material vulnerability such as reliance on payday lending, 
check-cashing stores, pawn shops, and other financial instruments that often require extreme repayment conditions and usurious interest rates. Moreover, while the poor have greater access to any single household appliance than in the past, it is still the case that the majority of them do not have access to the full set of washer, dryer, dishwasher, refrigerator, stove, and phone (Siebens 2013). In addition, during 2011 over 12 percent of households in the first income quintile faced three or more hardships such as trouble paying rent or utilities, or seeing a doctor, compared to 6 percent of all households (Siebens 2013).

This points to additional concerns about household economic security among the poor, whether it be in earnings, income, or the acquisition of food. The trends in higher inequality discussed previously could be due to a rise in overall earnings and income instability, a shift in permanent incomes, or both. However, if there is little corroborative evidence of a rise in instability then widening inequality is the likely outcome of lifetime changes in the distribution of earnings and income, the latter of which could have negative consequences for long-term economic mobility. Gottschalk and Moffitt (1994) pioneered research on documenting trends in earnings instability, and in particular on using longitudinal data from the PSID to decompose the trends into their permanent and transitory components. This decomposition is illustrative because it permits identification of temporary deviations of earnings from long-term trends, as well as identification of structural changes in long-term trends. They found that transitory earnings instability rose by over 40 percent from 1970 through the mid 1980s, and then more or less stabilized thereafter, while permanent variance rose primarily in the 1980s. More recent estimates by Gottschalk and Moffitt (2012) point to continued increased in permanent variance through 2004. Keys (2008) found that this basic pattern of earnings instability held across race, gender, education, and family structure in the PSID. Dynan, et al. (2012), using the PSID, and 
Hardy and Ziliak (2014), using matched panels from the CPS, focus on trends in total income volatility, finding that it rose through the 1990s and has remained at that higher level through the first decade of the 2000s.

While there are many papers documenting trends in earnings and income instability there is comparatively much less research on underlying mechanisms for the changes in volatility, and the attendant consequences. In particular, research is needed on life cycle patterns of volatility, especially the role of labor-force transitions. As emphasized by many in the literature the presence of rising volatility does not necessarily imply increased economic risk. Thus, research is needed on whether the labor force transitions leading to higher volatility are voluntary or involuntary, what role the business cycle has played, as well as changes in tax and transfer policies. Research is also needed on the effects of income instability on family and child well being, material and otherwise. Has the rise in permanent earnings instability increased family exposure to material hardships such as falling behind on rent or utilities disconnected? Work by Heflin and Butler (2013) and Heflin (2014) suggests that factors that affect material hardship are not the same as those that affect income changes, pointing to a greater role for household composition and disability status on material hardship. This work has been conducted on a limited sample in the Women’s Employment Study, and needs to be extended to national samples. In addition, does growing up in a family with unstable incomes affect long-term outcomes of the children? New evidence from Hardy (forthcoming) suggests that family income volatility has modest negative consequences for education attainment of the child, controlling for the level of parent income. More research along these lines is needed exploiting the rich context of longitudinal data.

Beyond earnings and income security, much attention has been placed on food insecurity 
Figure 5. Trends in Food Insecurity in the United States

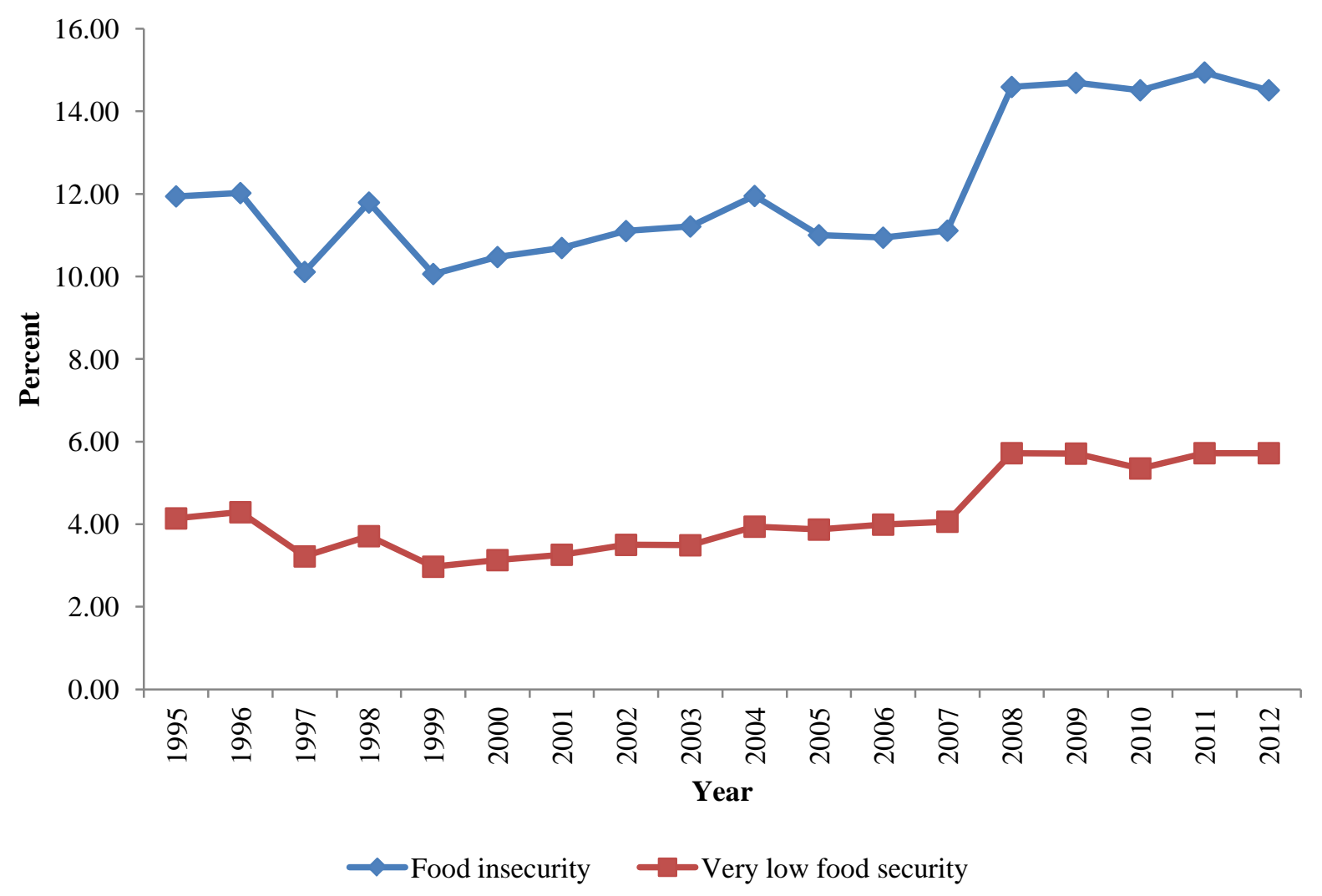

in recent years. The Life Sciences Research Office defined food insecurity as a situation that "exists whenever the availability of nutritionally adequate and safe foods or the ability to acquire acceptable foods in socially acceptable ways is limited or uncertain” (Anderson 1990). Socially acceptable means that it is not necessary to resort to emergency food supplies (food banks or pantries), scavenging, stealing, or other coping strategies. Starting in 1995 the U.S. Department of Agriculture began fielding the Core Food Security Supplement (CFSM) as part of the CPS, and since 2001 this has been a part of the December CPS. The CFSM is a series of 18 questions (10 if there are no children living in the household) that asks whether the household faced difficulties feeding themselves over the prior 12 months because of lack of money. (They also ask separately about the prior 30 days) These difficulties range from worry about running out of 
money to actually skipping meals for a whole day or more for a lack of money. Figure 5 depicts trends in the fraction of households facing food insecurity (=1 if at least 3 affirmative answers in the CFSM) and very low food security (=1 if at least 8 affirmative answers (6 if no children present)) from 1995 to 2012. Rates of food insecurity hovered in the 10-12 percent range until 2007 when they shot up 30 percent with the onset of the Great Recession and have remained elevated thereafter. At nearly 15 percent of the population in 2012, this means that about 50 million Americans are living in households facing food insecurity. A similar pattern held for very low food security, though the level of this severe hardship is less than half the overall rate of food insecurity.

Unlike the volatility and hardship literatures, there have been many studies documenting the determinants of food insecurity (see the survey by Gundersen, Kreider, and Pepper 2011). This work shows that families are at increased risk if they are poor, have low education, are African American (relative to white), are disabled, and are not married. However, what is also surprising is that half of the poor do not report problems with food security, suggesting that there are other mechanisms at work affecting food insecurity, and more research is needed on these factors, especially at the intersection of food insecurity, financial management skills, and material hardship. ${ }^{7}$ Additionally, we have little research on longitudinal aspects of food insecurity. Is it transmitted across generations? Does growing up as a child in a food insecure household have long-term consequences? Work by Hoynes, et al. (2013) showing that children with early exposure to the Food Stamp Program in the late 1960s and early 1970s experience better health outcomes as adults suggests that food insecurity does have negative consequences over time on child development, but direct evidence on this issue is highly needed given current rates of food insecurity in the United States.

\footnotetext{
${ }^{7}$ See Levy (2009) for an initial look at this issue among seniors age 65 and older in the HRS.
} 


\section{What Information Do We Collect on Income, Program Participation, Poverty, and Financial Vulnerability?}

This section presents a overview of national longitudinal datasets that are the primary survey-based resources for research on income, poverty, program participation, and financial vulnerability in the United States: the Consumer Expenditure Survey (CE); the Current Population Survey Annual Social and Economic Supplement (CPS ASEC); the Early Childhood Longitudinal Study Kindergarten Class of 2010-11 (ECLS-K: 2011); the Health and Retirement Study (HRS); the Medical Expenditure Panel Study (MEPS); the National Longitudinal Study of Youth 1979 (NLSY79); the National Longitudinal Study of Youth 1997 (NLSY97); the Panel Study of Income Dynamics (PSID); the Survey of Consumer Finances (SCF); and the Survey of Income and Program Participation (SIPP). The focus here is restricted to those surveys that aim to be nationally representative, whether of the whole population or certain subsets such as children (e.g. ECLS and NLSY) or older adults (e.g. HRS), and to those that are continuing data collection in the field. Consequently, certain panels such as the ECLS-K (Kindergarten Class of 1998-99) and ECLS-B (Birth Cohort of 2001), National Longitudinal Study of Adolescent Health (Add Health), Fragile Families and Child Well Being Study, and the Three-City Study, are not discussed because they are no longer in the field (or are not national in scope as in the Three-City Study), though they each continue to be heavily used datasets for research on family and child well being.

Table 2 summarizes the key features of these ten major panel datasets. The first panel contains basic information on survey design such as target population and sampling frequency; the second panel covers wage and family income information, including whether the data are top-coded; the third panel covers the range of transfer income information; the fourth panel 
covers variables related to material hardship; and the fifth panel of Table 2 covers household assets. Full treatment of each of these categories is beyond the scope of this paper, and the interested reader is referred to the respective website of each panel for more information. ${ }^{8}$

\section{A. Survey Design}

The longitudinal datasets are funded by a wide array of federal agencies - Agency for Healthcare Research and Quality, Bureau of Labor Statistics, Census Bureau, Federal Reserve Board, Department of Education, Department of Agriculture, National Institute of Health, National Institute on Aging, National Institute of Child Health and Human Development, National Science Foundation, and Social Security Administration—and the survey designs often reflect the aims and scopes of the agencies. As such, six of the panels use the full civilian noninstitutionalized population ages 15 (or 16) and older as the population of interest (CE, CPS ASEC, MEPS, PSID, SCF, and SIPP), three focus on specific cohorts of children (ECLSK:2011, NLSY79, NLSY97), and one on older Americans (HRS). ${ }^{9}$ In addition, most of the panels include an oversample of a specific demographic group or groups, usually by income (e.g. PSID, SCF, and SIPP), race (e.g. ECLS, HRS, MEPS, NLSY), or ethnicity (CPS, HRS, NLSY), and therefore adjust survey weights to account for this oversample. The stark implication is that because of their limited focus 40 percent of the panel surveys are categorically ruled out as potential resources for population-wide national income and poverty estimates.

The sampling frequency is very heterogeneous across the ten panels, as is the maximum number of periods in sample. Strictly the CE and CPS ASEC are not designed as panel surveys,

\footnotetext{
${ }^{8}$ See also the excellent surveys on key challenges facing panel surveys in Kasprzyk, et al. (1989), Citro and Michael (1995, especially Appendix B), Bound, Brown, and Mathiowetz (2001), and Groves (2001).

${ }^{9}$ The surveys of the entire civilian population generally include members of the Armed Forces who reside in nonbase housing.
} 
Table 2. National Household Panels in the United States: Design

\begin{tabular}{|c|c|c|c|c|c|c|}
\hline Panel & $\begin{array}{l}\text { Start Date } \\
\text { of Survey }\end{array}$ & Target Population & Oversample & Sampling Frequency & $\operatorname{Max} \mathbf{T}$ & $\begin{array}{c}\text { Follows Respondents that Move } \\
\text { within US }\end{array}$ \\
\hline $\begin{array}{l}\text { Consumer Expenditure Survey } \\
\text { (Interview Survey) }\end{array}$ & 1980 & U.S. civilian noninstitutional population & None & $\begin{array}{l}\text { Quarterly (with } \\
\text { monthly rotation groups) }\end{array}$ & 5 quarters & No \\
\hline $\begin{array}{c}\text { Current Population Survey } \\
\text { (Annual Social and Economic } \\
\text { Supplement) }\end{array}$ & 1948 & U.S. civilian noninstitutional population & Hispanics & Annual & 2 yrs & No \\
\hline $\begin{array}{l}\text { Early Childhood Longitudinal } \\
\text { Study (ECLS-K:2011) }\end{array}$ & 2010 & $\begin{array}{l}\text { Nationally representative sample selected } \\
\text { from both public and private schools } \\
\text { attending both full-day and part-day } \\
\text { kindergarten in 2010-11 }\end{array}$ & $\begin{array}{l}\text { Twins, Chinese, Other Asian and } \\
\text { Pacific Islander, Indian/Alaskan, low } \\
\text { birth weight children }\end{array}$ & $\begin{array}{l}\text { Biannual (fall and } \\
\text { spring) for 2010-11, } \\
\text { 2011-12, 2012-13; } \\
\text { Annual for spring of } \\
\text { 2014, 2015, } 2016\end{array}$ & 6 yrs & $\begin{array}{l}\text { Yes, but only a random subsample } \\
\text { of movers }\end{array}$ \\
\hline Health and Retirement Study & 1992 & Individuals Aged $50^{+}$ & $\begin{array}{l}\text { Black, } \\
\text { Hispanics, and Floridians }\end{array}$ & Biennial & NA & Yes \\
\hline $\begin{array}{l}\text { Medical Expenditure Panel } \\
\text { Survey }\end{array}$ & 1996 & U.S. civilian noninstitutional population & $\begin{array}{l}\text { Blacks, Hispanics, and starting in } \\
2006 \text { Asians. Also sub-groups such } \\
\text { as low income }\end{array}$ & Biannual & $2.5 \mathrm{yrs}$ & Yes \\
\hline $\begin{array}{l}\text { National Longitudinal Survey } \\
1979\end{array}$ & 1979 & $\begin{array}{l}\text { Individuals aged 14-21 by December 31, } \\
\qquad 1978\end{array}$ & $\begin{array}{l}\text { Blacks, Hispanics, economically } \\
\text { disadvantaged } \\
\text { nonblacks and non-Hispanics, and } \\
\text { youths in the military for certain years }\end{array}$ & $\begin{array}{l}\text { Annual; Biennially } \\
\text { after } 1994\end{array}$ & NA & Yes \\
\hline $\begin{array}{c}\text { National Longitudinal Survey } \\
1997\end{array}$ & 1997 & 12 to 16 years old as of December 31, 1996 & Black and Hispanics & $\begin{array}{l}\text { Annual; Biennial after } \\
2012\end{array}$ & NA & Yes \\
\hline $\begin{array}{l}\text { Panel Study of Income } \\
\text { Dynamics (PSID) }\end{array}$ & 1968 & U.S. Population excluding oversample & Low-income families & $\begin{array}{l}\text { Annual; Biennial after } \\
1997\end{array}$ & NA & Yes \\
\hline Survey of Consumer Finances & 1946 & U.S. Population excluding oversample & Wealthy families & Triennial & $2 \mathrm{yrs}$ & $\begin{array}{l}\text { Panel for } 1983-1989 \text { and } 2007- \\
2009 \text { periods }\end{array}$ \\
\hline $\begin{array}{l}\text { Survey of Income and Program } \\
\text { Participation }\end{array}$ & 1984 & U.S. Population excluding oversample & $\begin{array}{l}\text { Oversampling of low-income } \\
\text { families in } 1990 \text { \& } 1996\end{array}$ & $\begin{array}{l}\text { Triannual; Annual } \\
\text { starting in } 2014\end{array}$ & $\begin{array}{l}13 \text { waves for } \\
2008 ; 4 \text { yrs } \\
\text { for SIPP } \\
2014\end{array}$ & Yes \\
\hline
\end{tabular}


Table 2 Continued: Wage and Family Income

\begin{tabular}{|c|c|c|c|}
\hline Panel & Individual Wage Income & Family Income & Top Code Limit \\
\hline Consumer Expenditure Survey (Interview Survey) & Yes for members of consumer unit & $\begin{array}{l}\text { Yes for consumer unit over prior } 12 \text { months (may or may be } \\
\text { related persons) }\end{array}$ & 150,000 for wage income \\
\hline $\begin{array}{l}\text { Current Population Survey (Annual Social and } \\
\text { Economic Supplement) }\end{array}$ & Yes & Yes for prior calendar year & $\begin{array}{l}\text { \$250,000 earnings from longest job. Rank } \\
\text { swapping above top code as of } 2011\end{array}$ \\
\hline $\begin{array}{l}\text { Early Childhood Longitudinal Study (ECLS- } \\
\text { K:2011) }\end{array}$ & No & Total household income in prior calendar year & household income > \$200,000 \\
\hline Health and Retirement Study & Yes for both respondent and spouse & Yes for prior calendar year & $\begin{array}{l}\text { earnings are top-coded at the Social Security } \\
\text { maximum taxable wage for each year }\end{array}$ \\
\hline Medical Expenditure Panel Survey & Yes & $\begin{array}{c}\text { Yes, by summing up all family members for prior calendar } \\
\text { year }\end{array}$ & Hourly wage $>\$ 75.75$ \\
\hline National Longitudinal Survey 1979 & $\begin{array}{l}\text { Wage Income for all observations since } 1978 . \\
\text { Includes salary, wages and tips }\end{array}$ & Yes for prior calendar year & $\begin{array}{l}\text { Beginning in 1996, the algorithm takes the top } \\
\text { two percent of respondents with valid values } \\
\text { and averages them. That averaged value } \\
\text { replaces the values for all cases in the top } \\
\text { range }\end{array}$ \\
\hline National Longitudinal Survey 1997 & $\begin{array}{l}\text { The NLSY97 collects gross wage and salary } \\
\text { data for the past calendar year from all } \\
\text { respondents }\end{array}$ & Total household income in the prior calendar year & $\begin{array}{l}\text { For income variables, the top } 2 \text { percent of } \\
\text { reported values are topcoded and replaced with } \\
\text { the mean of the high values }\end{array}$ \\
\hline Panel Study of Income Dynamics (PSID) & $\begin{array}{c}\text { Yes for head, spouse, and other family unit } \\
\text { members }\end{array}$ & Yes for the prior calendar year & Wages and salaries top coded at $\$ 9,999,997$ \\
\hline Survey of Consumer Finances & Yes & $\begin{array}{l}\text { Yes for prior calendar year (based on Primary Economic Unit, } \\
\text { which may be larger or smaller than the family) }\end{array}$ & $\begin{array}{l}\text { Very limited top-coding; Excludes individuals } \\
\text { on Forbes } 400 \text { list }\end{array}$ \\
\hline Survey of Income and Program Participation & Monthly Individual Earned Income & Monthly family income & $\begin{array}{l}150,000 \text { for individuals (or 50,000 per month, } \\
\text { although the latter is rarely used) }\end{array}$ \\
\hline
\end{tabular}


Table 2 Continued: Transfer Income

\begin{tabular}{|c|c|c|c|c|c|c|c|c|c|c|c|}
\hline Panel & $\begin{array}{c}\text { Social } \\
\text { Security \$ }\end{array}$ & $\begin{array}{c}\text { Food } \\
\text { Stamps } \$\end{array}$ & SSI \$ & DI \$ & TANF $\$$ & EITC $\$$ & $\begin{array}{l}\text { Free/Reduced } \\
\text { Lunch }\end{array}$ & Medicaid & WIC & $\begin{array}{c}\text { Unemployment } \\
\$\end{array}$ & Public Housing \\
\hline $\begin{array}{l}\text { Consumer Expenditure } \\
\text { Survey (Interview } \\
\text { Survey) }\end{array}$ & Yes & Yes & Yes & No & $\begin{array}{l}\text { Total value } \\
\text { of all welfare } \\
\text { received }\end{array}$ & No & No & Yes & No & Yes & Yes \\
\hline $\begin{array}{l}\text { Current Population } \\
\text { Survey (Annual Social } \\
\text { and Economic } \\
\text { Supplement) }\end{array}$ & Yes & Yes & Yes & Yes & Yes & $\begin{array}{c}\text { Yes } \\
\text { (Simulated) }\end{array}$ & Yes (Simulated) & Yes & $\begin{array}{l}\text { Whether } \\
\text { Received }\end{array}$ & Yes & Yes \\
\hline $\begin{array}{l}\text { Early Childhood } \\
\text { Longitudinal Study } \\
\text { (ECLS-K:2011) }\end{array}$ & No & Yes. & No & No & Yes & No & Yes & No & Yes & No & Yes (in future) \\
\hline $\begin{array}{l}\text { Health and Retirement } \\
\text { Study }\end{array}$ & $\begin{array}{c}\text { Both } \\
\text { Respondent } \\
\text { and Spouse }\end{array}$ & Yes & $\begin{array}{l}\text { HH Amount } \\
\text { and who } \\
\text { received it }\end{array}$ & Yes & $\begin{array}{l}\text { Welfare } \\
\text { Question }\end{array}$ & No & No & Yes & No & Yes & Yes \\
\hline $\begin{array}{l}\text { Medical Expenditure } \\
\text { Panel Survey }\end{array}$ & Yes & Yes & Yes & Yes & $\begin{array}{c}\text { Some } \\
\text { measures } \\
\text { about receipt. }\end{array}$ & $\begin{array}{l}\text { Whether } \\
\text { Received }\end{array}$ & No & $\begin{array}{l}\text { Monthly } \\
\text { Medicaid } \\
\text { coverage } \\
\text { combined } \\
\text { with CHIP }\end{array}$ & No & Yes & No \\
\hline $\begin{array}{l}\text { National Longitudinal } \\
\text { Survey } 1979\end{array}$ & Yes & $\begin{array}{l}\text { Yes, except } \\
\text { 1979-1982 } \\
\text { basic } \\
\text { questions }\end{array}$ & Yes & $\begin{array}{c}\text { Yes, } \\
\text { combined } \\
\text { with } \\
\text { veteran's } \\
\text { payments } \\
\text { in earlier } \\
\text { waves }\end{array}$ & $\begin{array}{l}\text { Yes, except } \\
\text { 1979-1982 } \\
\text { basic } \\
\text { questions }\end{array}$ & No & No & Yes & Yes & $\begin{array}{l}\text { Every period } \\
\text { except } 1979\end{array}$ & $\begin{array}{c}\text { Rent Subsidy } \\
\text { questions 1979- } \\
2010 \text { also public } \\
\text { housing except } 1985\end{array}$ \\
\hline $\begin{array}{l}\text { National Longitudinal } \\
\text { Survey } 1997\end{array}$ & $\begin{array}{l}\text { Question on } \\
\text { "other" } \\
\text { welfare }\end{array}$ & Yes & $\begin{array}{l}\text { Question on } \\
\text { "other" } \\
\text { welfare }\end{array}$ & $\begin{array}{l}\text { Question } \\
\text { on "other" } \\
\text { welfare }\end{array}$ & $\begin{array}{l}\text { Yes, but } \\
\text { jointly with } \\
\text { spouse }\end{array}$ & $\begin{array}{l}\text { Whether } \\
\text { Received }\end{array}$ & $\begin{array}{l}\text { Question on } \\
\text { "other" welfare }\end{array}$ & $\begin{array}{l}\text { Might be able } \\
\text { to identify in } \\
\text { healthcare } \\
\text { coverage } \\
\text { section }\end{array}$ & $\begin{array}{l}\text { Joint } \\
\text { question } \\
\text { on } \\
\text { coverage }\end{array}$ & Yes & Yes \\
\hline $\begin{array}{l}\text { Panel Study of Income } \\
\text { Dynamics (PSID) }\end{array}$ & Yes & Yes & Yes & Yes & Yes & No & $\begin{array}{l}\text { Whether } \\
\text { Received }\end{array}$ & Yes & $\begin{array}{l}\text { Question } \\
\text { about } \\
\text { receipt }\end{array}$ & Yes & Yes \\
\hline $\begin{array}{l}\text { Survey of Consumer } \\
\text { Finances }\end{array}$ & Yes & $\begin{array}{l}\text { Combined } \\
\text { variable for } \\
\text { TANF, Food } \\
\text { Stamps, SSI, } \\
\text { and other } \\
\text { welfare }\end{array}$ & $\begin{array}{l}\text { Combined } \\
\text { variable for } \\
\text { TANF, Food } \\
\text { Stamps, SSI, } \\
\text { and other } \\
\text { welfare }\end{array}$ & Yes & $\begin{array}{l}\text { Combined } \\
\text { variable for } \\
\text { TANF, Food } \\
\text { Stamps, SSI, } \\
\text { and other } \\
\text { welfare }\end{array}$ & No & No & Yes & No & $\begin{array}{l}\text { Combined } \\
\text { variable for } \\
\text { Unemployment } \\
\text { and worker } \\
\text { compensation }\end{array}$ & Yes \\
\hline $\begin{array}{l}\text { Survey of Income and } \\
\text { Program Participation }\end{array}$ & Yes & Yes & Yes & Yes & Yes & Yes & $\begin{array}{l}\text { Whether } \\
\text { Received }\end{array}$ & Yes & Yes & Yes & Yes \\
\hline
\end{tabular}


Table 2 Continued: Material Hardship

\begin{tabular}{|c|c|c|c|c|c|c|c|c|c|}
\hline Panel & Expenditure Data & $\begin{array}{l}\text { Poverty } \\
\text { Indicator }\end{array}$ & $\begin{array}{l}\text { Has Health } \\
\text { Insurance }\end{array}$ & Disability & $\begin{array}{l}\text { Electricity or } \\
\text { Heating Shut } \\
\quad \text { Off }\end{array}$ & $\begin{array}{l}\text { Evicted from } \\
\text { Home /Late } \\
\text { on Payments }\end{array}$ & $\begin{array}{l}\text { Telephone } \\
\text { Shut Off }\end{array}$ & Food Insecurity & Notes \\
\hline $\begin{array}{c}\text { Consumer Expenditure Survey } \\
\text { (Interview Survey) }\end{array}$ & Yes & Yes & Yes & Yes & No & No & No & No & $\begin{array}{l}\text { Finance and } \\
\text { Late } \\
\text { Charges }\end{array}$ \\
\hline $\begin{array}{l}\text { Current Population Survey } \\
\text { (Annual Social and Economic } \\
\text { Supplement) }\end{array}$ & $\begin{array}{l}\text { Out of pocket childcare and } \\
\text { medical expenses starting in } \\
2011\end{array}$ & Yes & Yes & Yes & No & No & No & $\begin{array}{l}\text { No (but in December } \\
\text { Supplement) }\end{array}$ & \\
\hline $\begin{array}{l}\text { Early Childhood Longitudinal } \\
\text { Study (ECLS-K:2011) }\end{array}$ & $\begin{array}{l}\text { Some expenditures related to } \\
\text { child }\end{array}$ & Yes & Yes & $\begin{array}{l}\text { Yes, for } \\
\text { child }\end{array}$ & $\begin{array}{l}\text { Question about } \\
\text { not being able to } \\
\text { pay bills }\end{array}$ & Yes & $\begin{array}{l}\text { Question about } \\
\text { not being able to } \\
\text { pay bills }\end{array}$ & $\begin{array}{l}\text { Yes, in first Spring } \\
\text { Parent Interview }\end{array}$ & \\
\hline Health and Retirement Study & Yes, total spending & Yes & Yes & Yes & No & No & No & Yes & \\
\hline $\begin{array}{c}\text { Medical Expenditure Panel } \\
\text { Survey }\end{array}$ & Healthcare expenditure & Yes & Yes & Yes & No & No & No & No & \\
\hline $\begin{array}{l}\text { National Longitudinal Survey } \\
1979\end{array}$ & No & Yes & Yes & Yes & No & No & No & No & \\
\hline $\begin{array}{c}\text { National Longitudinal Survey } \\
1997\end{array}$ & Child care spending & No & $\begin{array}{l}\text { Yes, after } \\
\text { round } 6\end{array}$ & Yes & No & No & No & No & \\
\hline $\begin{array}{l}\text { Panel Study of Income } \\
\text { Dynamics (PSID) }\end{array}$ & $\begin{array}{l}\text { Yes (only food/housing prior } \\
\text { to 1999) }\end{array}$ & Yes & Yes & Yes & No & Yes & No & $\begin{array}{l}\text { Yes, in 1999-2003 } \\
\text { surveys, and } 1997 \\
\text { Child Supplement }\end{array}$ & $\begin{array}{l}\text { Has loans } \\
\text { from } \\
\text { relatives }\end{array}$ \\
\hline Survey of Consumer Finances & No & No & Yes & Yes & No & No & No & No & $\begin{array}{l}\text { Payday loan } \\
\text { variable } \\
\text { with reason } \\
\text { for loan }\end{array}$ \\
\hline $\begin{array}{c}\text { Survey of Income and Program } \\
\text { Participation }\end{array}$ & $\begin{array}{l}\text { Some measures in topical } \\
\text { modules such as work- } \\
\text { related, medical, and child } \\
\text { related expenses }\end{array}$ & $\begin{array}{l}\text { Poverty Line for } \\
\text { Family in dollars } \\
\text { per month }\end{array}$ & Yes & Yes & Yes & Yes & Yes & Yes & \\
\hline
\end{tabular}


Table 2 Continued: Assets

\begin{tabular}{|c|c|c|c|c|c|c|c|c|c|}
\hline Panel & Frequency Observed & $\begin{array}{l}\text { Net Worth } \\
\text { Variable }\end{array}$ & $\begin{array}{c}\text { Home } \\
\text { Ownership }\end{array}$ & $\begin{array}{c}\text { Car } \\
\text { Ownership }\end{array}$ & $\begin{array}{c}\text { Cash Holdings } \\
\text { (\$) }\end{array}$ & CDs & Common Stock & IRA & $401 K / 403 B$ \\
\hline $\begin{array}{c}\text { Consumer Expenditure } \\
\text { Survey (Interview } \\
\text { Survey) }\end{array}$ & Some Measures & Can generate & Yes & Yes & Yes & No & $\begin{array}{l}\text { Includes mutual } \\
\text { funds, private } \\
\text { bonds, } \\
\text { government } \\
\text { bonds } \\
\text { and Treasury } \\
\text { notes }\end{array}$ & No & No \\
\hline $\begin{array}{l}\text { Current Population } \\
\text { Survey (Annual Social } \\
\text { and Economic } \\
\text { Supplement) }\end{array}$ & No & No & No & No & No & No & No & No & No \\
\hline $\begin{array}{l}\text { Early Childhood } \\
\text { Longitudinal Study } \\
\text { (ECLS-K:2011) }\end{array}$ & $\begin{array}{l}\text { None in first } 2 \text { parent } \\
\text { interviews }\end{array}$ & $\begin{array}{c}\text { None in first } 2 \\
\text { parent } \\
\text { interviews }\end{array}$ & $\begin{array}{c}\text { None in first } 2 \\
\text { parent } \\
\text { interviews }\end{array}$ & $\begin{array}{c}\text { None in first } 2 \\
\text { parent } \\
\text { interviews }\end{array}$ & $\begin{array}{c}\text { None in first } 2 \\
\text { parent } \\
\text { interviews }\end{array}$ & $\begin{array}{c}\text { None in first } 2 \text { parent } \\
\text { interviews }\end{array}$ & $\begin{array}{c}\text { None in first } 2 \\
\text { parent } \\
\text { interviews }\end{array}$ & $\begin{array}{c}\text { None in first } 2 \\
\text { parent } \\
\text { interviews }\end{array}$ & $\begin{array}{c}\text { None in first } 2 \\
\text { parent } \\
\text { interviews }\end{array}$ \\
\hline $\begin{array}{l}\text { Health and Retirement } \\
\text { Study }\end{array}$ & Each Survey & Yes & Yes & $\begin{array}{l}\text { Total value of } \\
\text { cars, trucks, } \\
\text { trailers, motor } \\
\text { homes, boats, } \\
\text { and airplanes. }\end{array}$ & Yes & $\begin{array}{l}\text { Includes CDs, } \\
\text { Government Savings } \\
\text { Bonds, and Treasury } \\
\text { Bills }\end{array}$ & Yes & Yes & $\begin{array}{c}\text { Some } \\
\text { questions }\end{array}$ \\
\hline $\begin{array}{l}\text { Medical Expenditure } \\
\text { Panel Survey }\end{array}$ & Not in Public Use Files & $\begin{array}{l}\text { Not in Public } \\
\text { Use Files }\end{array}$ & $\begin{array}{l}\text { Not in Public } \\
\text { Use Files }\end{array}$ & $\begin{array}{l}\text { Not in Public } \\
\text { Use Files }\end{array}$ & $\begin{array}{l}\text { Not in Public } \\
\text { Use Files }\end{array}$ & Not in Public Use Files & $\begin{array}{l}\text { Not in Public } \\
\text { Use Files }\end{array}$ & $\begin{array}{l}\text { Not in Public } \\
\text { Use Files }\end{array}$ & $\begin{array}{l}\text { Not in Public } \\
\text { Use Files }\end{array}$ \\
\hline $\begin{array}{l}\text { National Longitudinal } \\
\text { Survey } 1979\end{array}$ & $\begin{array}{l}\text { Asset Questions Asked 1985- } \\
\text { 1990, 1992-1994, 1996, 1998, } \\
\text { 2000, 2004, 2008. No asset } \\
\text { questions were included in the } \\
\text { 1991, 2002, } 2006 \text { and } 2010 \\
\text { surveys (also 1983-1984 } \\
\text { except home ownership) }\end{array}$ & $\begin{array}{l}\text { Yes, generated } \\
\text { from income } \\
\text { and liability } \\
\text { variables }\end{array}$ & $\begin{array}{l}\text { Yes for each } \\
\text { survey that asset } \\
\text { questions are } \\
\text { asked. Also } \\
\text { includes value } \\
\text { and amount } \\
\text { owed on } \\
\text { property }\end{array}$ & $\begin{array}{l}\text { Yes for each } \\
\text { survey that } \\
\text { asset questions } \\
\text { are asked. } \\
\text { Also includes } \\
\text { value and } \\
\text { amount owed } \\
\text { on car }\end{array}$ & $\begin{array}{l}\text { Yes for each } \\
\text { survey that } \\
\text { asset questions } \\
\text { are asked }\end{array}$ & $\begin{array}{c}\text { Each Survey 1994- } \\
2008\end{array}$ & $\begin{array}{c}\text { Each Survey } \\
1988-2008\end{array}$ & $\begin{array}{l}\text { Each Survey } \\
1994-2008\end{array}$ & $\begin{array}{c}\text { Each Survey } \\
1994-2008\end{array}$ \\
\hline
\end{tabular}


Table 2 Continued: Assets

\begin{tabular}{|c|c|c|c|c|c|c|c|c|c|}
\hline Panel & Frequency Observed & $\begin{array}{l}\text { Net Worth } \\
\text { Variable }\end{array}$ & $\begin{array}{c}\text { Home } \\
\text { Ownership }\end{array}$ & $\begin{array}{c}\text { Car } \\
\text { Ownership }\end{array}$ & $\begin{array}{c}\text { Cash } \\
\text { Holdings (\$) }\end{array}$ & CDs & $\begin{array}{c}\text { Common } \\
\text { Stock }\end{array}$ & IRA & $401 K / 403 B$ \\
\hline $\begin{array}{l}\text { National Longitudinal } \\
\text { Survey } 1997\end{array}$ & $\begin{array}{l}\text { Rounds 1-3. Respondents were } \\
\text { asked assets questions if they } \\
\text { were age } 18 \text { as of the previous } \\
\text { calendar year reference date } \\
\text { (12/31/1998 for round 3), or if } \\
\text { they met one of the other } \\
\text { independence criteria. Rounds } 4 \\
\text { and up. Respondents were asked } \\
\text { assets questions if they were } \\
\text { newly independent or if they } \\
\text { were age } 18 \text { as of the interview } \\
\text { date. In addition, respondents } \\
\text { were asked assets questions } \\
\text { again in the first interview after } \\
\text { they turned age } 20 \text {. A similar } \\
\text { series of asset questions are } \\
\text { asked again when the respondent } \\
\text { is } 25 \text {. However, in rounds } 9 \text { and } \\
\text { up these are asked of the birth } \\
\text { cohort rather than relying on age } \\
\text { as of interview date. }\end{array}$ & Yes & $\begin{array}{l}\text { Yes, since the } \\
\text { assets section of } \\
\text { the questionnaire } \\
\text { first determines if } \\
\text { respondents rent } \\
\text { or own their } \\
\text { dwelling place }\end{array}$ & $\begin{array}{l}\text { Yes, when } \\
\text { asset questions } \\
\text { asked }\end{array}$ & $\begin{array}{l}\text { Yes, when } \\
\text { asset questions } \\
\text { asked. }\end{array}$ & $\begin{array}{l}\text { Yes, when asset } \\
\text { questions asked. }\end{array}$ & $\begin{array}{l}\text { Yes, when } \\
\text { asset questions } \\
\text { asked. }\end{array}$ & $\begin{array}{l}\text { Combined } \\
\text { with Other } \\
\text { Assets }\end{array}$ & $\begin{array}{l}\text { Combined } \\
\text { with Other } \\
\text { Assets }\end{array}$ \\
\hline $\begin{array}{l}\text { Panel Study of Income } \\
\text { Dynamics (PSID) }\end{array}$ & $\begin{array}{l}\text { 1984, 1989, 1994, each wave } \\
\text { since } 1999\end{array}$ & Yes & Yes & Yes & Yes & $\begin{array}{l}\text { Yes, combined with } \\
\text { checking, savings }\end{array}$ & Yes & Yes & Yes \\
\hline $\begin{array}{l}\text { Survey of Consumer } \\
\text { Finances }\end{array}$ & Each Survey & $\begin{array}{l}\text { Yes, but must } \\
\text { be generated }\end{array}$ & Yes & Yes & $\begin{array}{l}\text { Yes for both } \\
\text { checking and } \\
\text { savings } \\
\text { accounts }\end{array}$ & Yes & Yes & Yes & $\begin{array}{l}\text { Can identify if } \\
\text { have not sure } \\
\text { about amount }\end{array}$ \\
\hline $\begin{array}{l}\text { Survey of Income and } \\
\text { Program Participation }\end{array}$ & Usually twice per survey & Yes & $\begin{array}{c}\text { Yes, and equity } \\
\text { asked in A\&L } \\
\text { modules }\end{array}$ & Yes & $\begin{array}{c}\text { In checking } \\
\text { and savings } \\
\text { accounts }\end{array}$ & & Yes & Yes & Yes \\
\hline
\end{tabular}


but there is a longitudinal dimension to each. In the case of the CE the consumer unit (which may or may not contain related individuals) is interviewed for five quarters, though the first quarter is generally used for anchoring purposes only, and then the unit is rotated out of the panel which means there is a maximum of four quarters of complete data. If the consumer unit moves during the sample period they are not followed and instead the CE interviews the new resident. The rotation of the CPS is that a respondent is in sample four months, out for eight months, and back in for another four months. This means that it is possible to link upwards of 50 percent of the CPS ASEC respondents from one March to the next, creating a series of two-year panels. Like the CE, if a respondent moves they are not followed and instead the new resident is interviewed. In both cases, great caution is required to guarantee that a longitudinal link is with the same unit, and associated attention to potential attrition bias from changes in sample composition. Bollinger and Hirsch (2013) suggest that matched CPS panels actually reduce measurement error in annual earnings reports compared to the cross-sections, which is beneficial for research on earnings dynamics.

Of the remaining eight surveys, only four have open-ended time horizons—HRS, NLSY79, NLSY97, and PSID—and the other four are time limited. The ECLS-K:2011 is scheduled to end in 2016 when the kindergarten cohort of 2010-11 reaches the $5^{\text {th }}$ grade, the MEPS rotates survey respondents out after five interviews over a two and a half year horizon, the SIPP 2008 followed respondents for thirteen waves ending in 2014 and the SIPP 2014 is slated to be a four-year panel through 2018, and finally the SCF is a cross-section fielded every three years that on two occasions has been extended into a two-year panel and as of this writing it is unknown whether another panel will be fielded. It is included in this review because of its unique status of being population wide and with an oversample of wealthy persons. 
Three of the four open-ended panels are fielded biennially (HRS, NLSY79, and PSID), though of these only the HRS was designed initially with this sampling horizon. The NLSY79 switched to every-other-year interviews in 1994 and the PSID in 1997, both the result of budget cuts from funding agencies. This means that the only open-ended panel with annual interviewing is the NLSY97. In general this does not pose a challenge for most panel analyses assuming the one-year gap is missing at random, and in fact in some cases may reduce measurement error (Griliches and Hausman 1986), though it does impose some limits on the types of dynamic models that can be identified (Holtz-Eakin, Newey, and Rosen 1988). Most of the questions in the biennial panels focus on the current and prior year, with some two-year recall on select outcomes. Starting in 1984 the PSID added an event history calendar of monthly dating for select labor-market outcomes and transfer-income data, which permits research on within-year dynamics. The SIPP was designed as a monthly panel for this purpose, and the triannual interviews were an attempt to minimize recall error. However the redesigned SIPP 2014 is now a once-a-year interview with a detailed event history calendar across a wide domain of family structure, economic, and health outcomes.

The PSID and NLSY79 follow children as they age out of the household to form their own units and thus are amenable to intergenerational analyses. ${ }^{10}$ The PSID has followed splitoffs from the inception of the panel, and in 1986 the Bureau of Labor Statistics started following the children of the NLSY79 to form the NLSY79 Child/Young Adult Sample. Because of the limitation of the NLSY79 to the cohort of 14-21 year olds at the end of 1978, the PSID is the only population-wide panel survey for intergenerational research, making it uniquely

\footnotetext{
${ }^{10}$ The HRS, however, does collect information on intervivos transfers of time and money that permit some analyses across generations.
} 
situated to address many of the questions raised above on intergenerational mobility, poverty persistence, and intergenerational dependence.

\section{B. Wage Income, Nonresponse, and Top Coding}

Beyond basic demographics, perhaps the two most heavily utilized variables in any panel survey are the individual's wage income and a summary measure of family or household income. Most of the surveys collect earnings data for the head of the unit as well as the spouse, and in some cases include individualized earnings for the whole roster of persons of age in the unit (e.g. CE, SIPP) or a combined measure of other family members (e.g. PSID). With the exception of the SIPP, the earnings and income data refer to the prior calendar year (or 12 months in the case of the CE). Because the focal unit of analysis varies across the surveys-family, consumer unit, household—some of the surveys provide an aggregated measure total income for the unit and some require the researcher to combine earnings and incomes from individual measures. In a few cases, it is not possible to separately identify family income (only members related by birth, marriage, or adoption) from a household income (incomes of those related or not). This can limit those panels for certain analyses, in particular where the focus is strictly on related persons in the nuclear family.

Two significant challenges face panel surveys of earnings and income, nonresponse and top-coding. Nonresponse can be in the form of initial survey nonresponse (i.e. refuse to participate in the survey or unable to contact), wave nonresponse (i.e. refuse or fail to locate the respondent for follow-up interviews), or item nonresponse (i.e. the respondent either refuses to provide data, or does not know the answer) (Groves 2001). Initial survey nonresponse can be as low as 10 percent in the CPS ASEC and NLSY79 to as high as 25 percent in the CE, PSID, and SIPP (Frankel, McWilliams, and Spencer 1983 ; Hill 1992; Johnson-Herring and Krieger 2008; 
Hokayem, Bollinger, and Ziliak 2014). Wave nonresponse is much less severe for most of the panels, roughly 2-3 percent per year, though cumulative attrition can be quite significant for long panels (Schoeni, et al. 2013). Likewise, wave nonresponse is higher for those few panels that do not follow sample members and instead survey household addresses (CE, CPS ASEC, ECLS-K: 2011). Moreover, the panels also differ on whether they admit wave nonresponders who do not die in between waves back into the panel (e.g. NLSY) or they do not (e.g. PSID, though starting in 1993 the PSID started recontacting attriters). Item nonresponse, especially as it pertains to earnings and income, can be quite high. For example, Figure 6, which is reproduced from Hokayem, Bollinger, and Ziliak (2014), shows that earnings nonresponse in the CPS ASEC has trended upward significantly since 1990, from just under 20 percent of all cases to about 33 percent each year since 2000. About two-thirds of the earnings nonresponse is on the earnings questions (mostly as it pertains to the longest job) and the other one-third is wave nonresponse. These rates of item nonresponse on earnings tend to be only half as large in the SIPP, and lower still in the PSID. It is generally believed that the worse response rates in the CPS ASEC stems from the fact that the primary mission of the CPS is as a monthly employment survey and not an income survey like SIPP, PSID, and NLSY.

Whether and to what extent earnings and income nonresponse is of concern depends on the relationship between the reason the variable is missing and the earnings/income level. If the earnings are missing completely at random (MCAR), which means the missing data are unrelated to both observable and unobservable factors, or missing at random (MAR), which means the missing data are unrelated to unobservables but are related to observables (but not the variable of interest), then nonresponse will impart no bias in estimates of population statistics, though it can reduce their efficiency. If, however, the data are missing nonrandomly (MNR) because it is 


\section{Figure 6. Trends in Item and Total (Item + Supplement) Imputations of Earnings in the CPS ASEC}

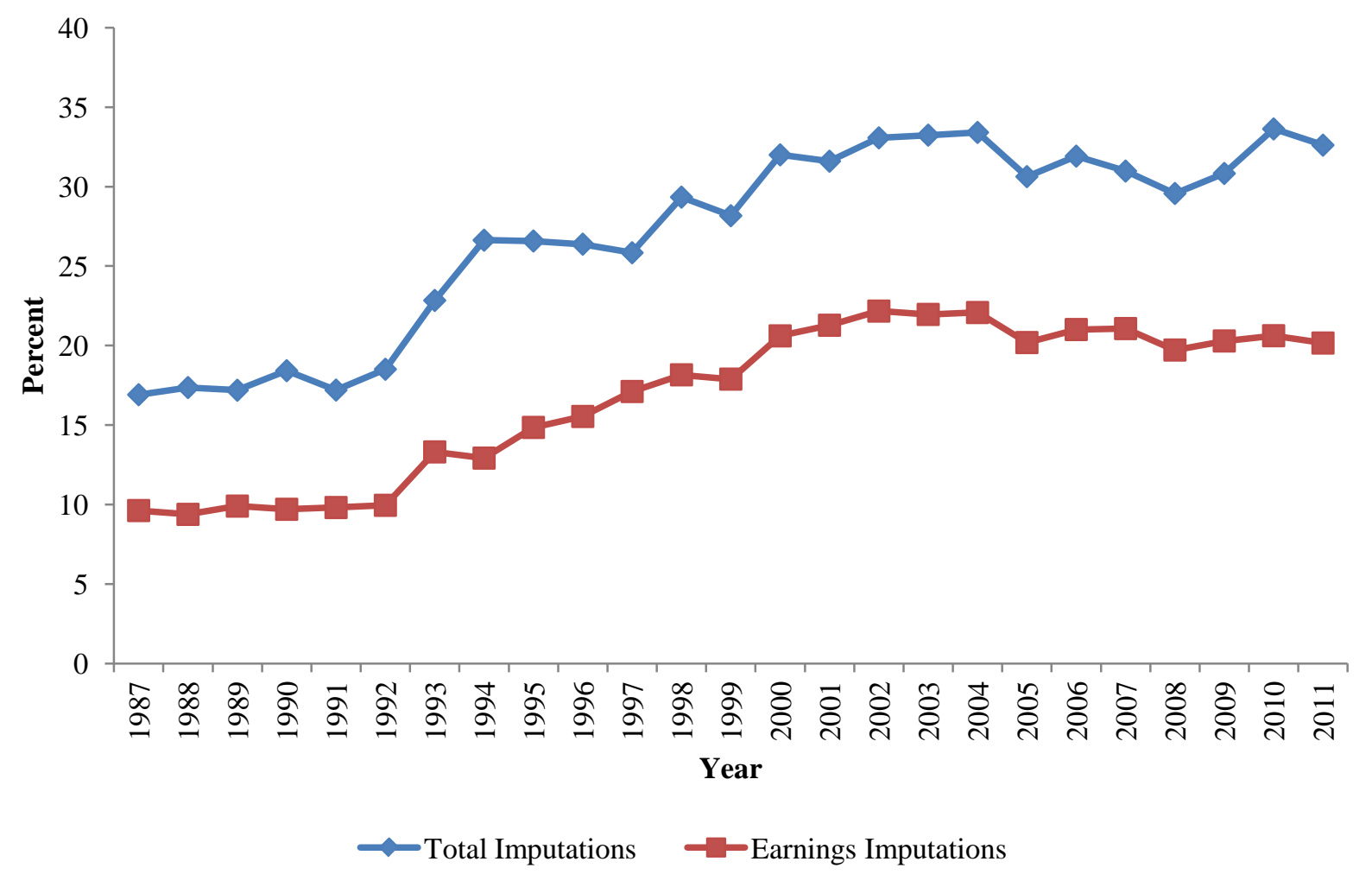

Source: Hokayem, Bollinger, and Ziliak (2014)

related to unobservables, then estimates may be biased. Virtually all the panels assume nonresponse is MAR by adjusting initial survey and panel-wave weights for differential nonresponse, and by utilizing a so-called hot deck or related imputation procedure for item nonresponse (and in some cases, wave nonresponse as in CPS ASEC). Little is known about bias from initial survey nonresponse, at least compared to wave and item nonresponse, and the MAR assumption may or may not be reasonable. While cumulative wave-to-wave attrition in the NLSY79, PSID, and SIPP is large, the series of papers in a special issue of Journal of Human Resources suggest that little bias is imparted on regression analyses of wages, hours of work, marriage, and other outcomes in these panels (Fitzgerald, Gottschalk, and Moffitt 1998; 
MaCurdy, Mroz, and Gritz 1998; Lillard and Panis 1998; Zabel 1998; Ziliak and Kniesner 1998). Fitzgerald (2011) finds that intergenerational correlations in earnings and health are little affected by attrition in the PSID, suggesting that the PSID maintains representativeness over time in this important research domain.

Hokayem, et al. (2014), using CPS ASEC data matched to Social Security Detailed Earnings Records (DER), show that nonresponse in the residual earnings distribution is Ushaped—high in both the lower and upper tails. This suggests that unobservables are at work and may lead to potentially confounding estimates of poverty in the left tail and inequality in the right tail that could be exacerbated in the initial stages of data collection. Moreover, their analysis, and that in Bollinger and Hirsch (2013), calls into question whether hot deck imputation procedures utilized by Census, BLS, and other agencies to assign missing earnings data under the MAR assumption is correct. Hirsch and Shumacher (2004) and Bollinger and Hirsch (2006) study the hot deck procedure in both the CPS ASEC and the CPS Outgoing Rotation Group, and show the hot deck procedure causes earnings regression parameters to be biased, sometimes by as much as 25 percent (e.g. the union wage differential). They recommend dropping observations with imputed earnings, or to possibly supplement that by estimating a saturated model of the probability of nonresponse and applying an inverse probability weighting estimator. How earnings imputations are handled in the wider literature varies considerably. Even within the inequality literature there is no stated consensus, e.g. Lemieux (2006) and Autor, Katz, and Kearney (2008) drop imputed earners, but Burkhauser, et al. (2012) retains those observations. In addition to nonresponse, an issue that poses substantive challenges for inequality research is top-coding of incomes. For example, the CE and SIPP top code wage income at $\$ 150,000$, the HRS at the maximum ceiling for Social Security payroll taxes (\$117,000 in 2014), 
and the CPS ASEC at $\$ 250,000 .^{11}$ On the other hand, the PSID has a comparatively high top code of \$9,999,997 for wages and salaries, the NLSY averages the top two percent of reported earnings and replaces the actual values with the mean, and the SCF has essentially a non-binding top code at a dollar below $\$ 10$ billion.

As the workhorse of inequality research in the U.S., top coding in the CPS ASEC has taken on a significant role. Until 1995 the Census Bureau used a fixed top code value, but from 1996-2010 they replaced the fixed constant with the cell mean of actual income above the top code based on a set of characteristics. Starting in 2011 they replaced the cell mean with a procedure known as “rank proximity swapping," which ranks incomes from lowest to highest above the top code and randomly swap actual values within a bounded range. The constraint of top codes in the CPS ASEC has led some to eschew the survey altogether in favor of tax return data (Piketty and Saez 2003; Chetty, et al. 2014). To see why, Figure 7 presents trends from 1997-2008 in the $99^{\text {th }}$ percentile of earnings among full-time, full-year workers in data that matches the internal CPS ASEC to tax return data in the DER. In the figure p99 refers to the $99^{\text {th }}$ percentile in the CPS ASEC, p99_noimputes drops those observations with imputed earnings in the ASEC, and p99_der replaces all CPS earnings data with earnings from the DER when a match is possible (and retains CPS data when no match is possible). Two observations are worth noting here: first, the CPS hot deck procedure seems to be improving estimates of earnings in the right tail since the $99^{\text {th }}$ percentile is everywhere higher than when imputes are dropped; second, in most years, especially in the second half of the sample, the ASEC, even with the hot deck, seems to substantively underestimate the high earners relative to the DER (\$50,000 gap in 2008). As this comparison is with the internal CPS ASEC with a top code four times higher than in the

\footnotetext{
${ }^{11}$ The CPS ASEC top code is \$1.1 million for researchers using “internal” data at Census or one of the Research Data Centers.
} 
Figure 7. Trends in 99th Percentile of Earnings for Full-Time, Full-Year Workers in Matched CPS ASEC-DER File

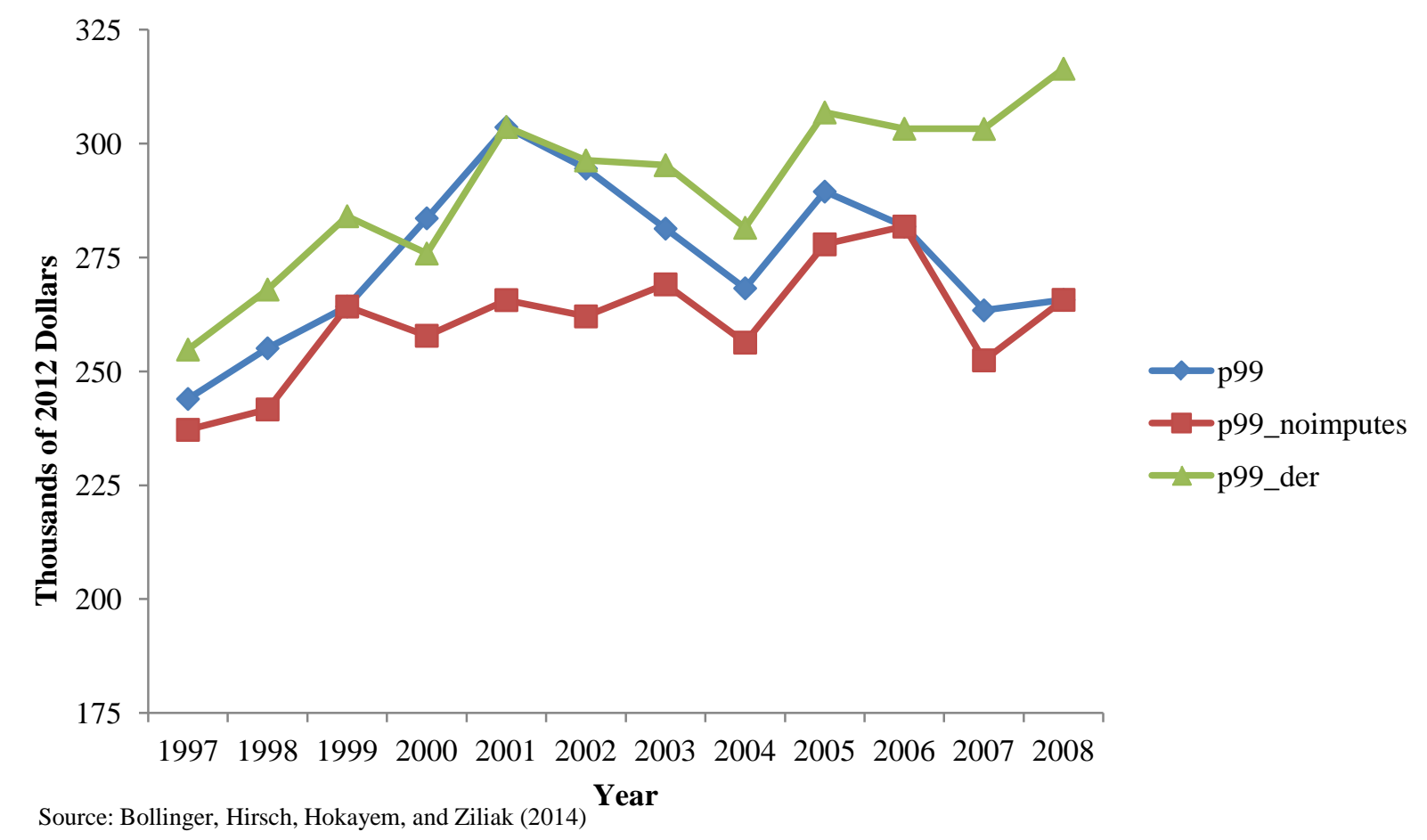

public release version of the data, the gap is likely more extreme than presented for most researchers.

The most common work-around for top coding in the CPS is to assume that the distribution of income above the top code follows a Pareto distribution, and to inflate the earnings values by a factor of 1.4 or 1.5 (Lemieux 2006; Autor, et al. 2008). This helps, but as Armour, et al. (2014) recently show, it does not go quite far enough. They instead use internal CPS ASEC data to estimate the Pareto parameter, and then to construct a top-code cell mean series to use in place of the top code produced by Census for the public release version of the data. They find this new series tracks the level and trend of inequality in tax return data better than the fixed-multiple adjustment of 1.4. As their data end in 2007, it is not known whether the rank proximity swapping procedure is now doing a more effective job at the top. 


\section{Transfer Income and Underreporting}

The three panel surveys that clearly stand out in terms of coverage of various transfer programs are the SIPP, the PSID, and the CPS ASEC. Each of these surveys provide indicators for whether a transfer was received and in most cases the dollar amount received. The SIPP provides the income information monthly, while the CPS ASEC and PSID for the prior calendar year. However, the PSID does ask respondents which months they (or someone in the home) participated in the program, permitting estimation of more dynamic models of transfers. The new SIPP 2014 panel will be more like the PSID with the move to once a year interviewing and collecting monthly recall information on program participation. The difference is that the PSID simply asks a roster of months and the SIPP 2014 will utilize an event history calendar (EHC) approach based on "event prompts" that is supposed to add precision to when a spell starts and stops. ${ }^{12}$ Even though coverage of the panoply of programs is impressive in these three panels, they are still are lacking in some areas. For example, actual receipt of the EITC (participation and dollar amount) is missing in both the PSID and CPS ASEC, though there is a simulated value in the CPS, and disability income is pooled with other Social Security income (retirement,survivors) in the SIPP and PSID, making it a challenge to isolate DI receipt. While it ultimately is possible to identify DI income in the CPS ASEC, it requires several variables to disentangle from other Social Security sources. Given the size of the DI and EITC programs this is a clear shortcoming in these three panels.

Perhaps the overarching concern over the past two decades about transfer programs in household surveys is underreporting of receipt, and conditional on receipt, underreporting of

\footnotetext{
${ }^{12}$ The PSID uses an EHC for employment, housing, and migration topics. See Beaule, Leissou, and Lui (2007) for a discussion of the PSID experience with EHCs. The NLSY97 also uses a similar, but more structured, event history data (EHD) approach for transfer programs and a host of other demographic variables (Pierret, et al. 2007). The distinction is that the NLSY97 does not use events across domains as "triggers" to assist in dating events.
} 
dollar amount of assistance. Wheaton (1997) reports that the fraction of AFDC/TANF caseload captured in the CPS ASEC compared to administrative totals fell from 74 percent in 1993 to 59 percent in 2005; food stamps from 67 percent to 57 percent; SSI from 83 percent to 74 percent; and Medicaid/SCHIP from 87 percent to 72 percent. The rates of annual dollar benefits captured in the CPS ASEC is similar to the caseload rates. She also examines underreporting in the SIPP for calendar years 1997 and 2002, and finds that the SIPP does much better than the CPS ASEC in terms of dollars captured for both food stamps and SSI (actually SIPP is little different than admin totals for SSI), but does equally bad for AFDC/TANF. Meyer, Mok, and Sullivan (2009) add to Wheaton's work by examining ten transfer programs and five surveys—CPS ASEC, SIPP, PSID, CE, and the American Community Survey (ACS). They show that in recent years the CPS ASEC, PSID, and CE captured less than half of TANF dollars, but this number rises to about 60 percent in the SIPP, and 80 percent in the ACS. The PSID and SIPP capture about 80 percent of food stamps, but the other surveys only capture about 60 percent. On the other hand, all the surveys cover Social Security well, including disability insurance (to the extent it can be identified), but SSI less well (except for SSI in the SIPP). Rates of UI coverage hover around 70 percent in most of the surveys, except the CE where it is closer to 50 percent. There is no discernible trend in reporting rates for Social Security, DI, SSI, or UI. Reporting rates for Workers Comp is poor in all surveys.

This underreporting has implications for both the official and supplemental poverty measures, inequality estimates, and intergenerational dependence; in short, it negatively affects all the major research domains raised earlier. To give one basic example, much attention has been given to the rise of "disconnected" mothers after welfare reform, i.e. those single mothers who are neither in work nor on welfare (usually defined as AFDC/TANF and food stamps), 
raising alarms as to how they are making ends meet (Blank and Kovak 2008). A confounding factor is that the increase in the rate of disconnectedness coincides with an increasing rate of underreporting in surveys, so that some of this trend could be a spurious result of misreporting in household panels.

The reasons for underreporting are not well understood. It could come in part from stigma, recall error, and confusion over program names. A good example of the latter is the AFDC/TANF program. Prior to the 1996 welfare reform the name AFDC was ubiquitous across the states, though sometimes paired with General Assistance or Emergency Assistance programs. With the establishment of TANF, only 9 states along with the District of Columbia actually call the program TANF. Alternative program names include EMPOWER (Arizona), ABC (Delaware), Work First (North Carolina), and W-2 (Wisconsin). Disability is another area where there can be confusion: DI, SSI, Workers Comp, employer-provided etc... And in 2008 after forty-four years the Food Stamp Program was renamed the Supplemental Nutrition Assistance Program (SNAP). But again states were given the option to adopt the SNAP name and only half chose to do so; others kept the name food stamps, while some others went a different direction altogether such as 3SquaresVT in Vermont. Although survey interviewers are usually prompted to use the local name, it is not known how systematic this is across surveys and over time.

Another possible reason for the rise in underreporting, at least as it applies to TANF, is the fact that today only about 30 percent of TANF appropriations are delivered in the form of cash assistance. The remaining 70 percent includes expenditures on child care, workforce development, and various programs designed to improve family structure and family life such as reduced out-of-wedlock childbearing, early childhood investments, and substance abuse treatment, among others. These percentages are exactly reversed from the typical allocation of 
funds in the pre-welfare reform era. If a welfare client does not receive cash but only in-kind transfers from the TANF office it is not obvious whether or not they would be recorded as a welfare recipient in the survey. For example, the TANF question in the CPS ASEC reads “At any time during [19xx/20xx] (last year) even for one month did anyone in this household receive: Any public assistance or welfare payments from the State or local welfare office?” The wording seems to preclude in-kind assistance from TANF. However, it may capture other forms of welfare assistance such as “diversion” payments, which are made in several states to potential welfare recipients in lieu of registering the client on the welfare caseload.

A broader concern for survey measurement of transfer programs is the fact that valuing in-kind transfers is a significant challenge, and the importance of such transfers has only grown in proportion to total expenditures on relief over the past two decades making such valuation even more critical. At the time of Smeeding’s (1982) report for the Census Bureau, expenditures on in-kind transfers outnumbered cash transfers by 2 to 1; today, in-kind transfers exceed cash transfers by a factor closer to 10 to 1 . This list includes Medicaid, Medicare, food stamps, school breakfast and lunch, WIC, public housing and Section 8 vouchers, Head Start, and now TANF. Research on how effective we capture in-kind transfers is scant, and whether the growth of in-kind transfers has had a negative spillover on transfer reporting as a whole, even for cash programs, is not known but seems critical for a more accurate assessment of the safety net.

\section{Material Hardship and Wealth}

The remaining three panels of Table 2 summarize measures of material hardship and assets collected in the ten major panel surveys. In the case of material hardship the coverage is considerably more sparse than the various measures of income, both earned and unearned. The broadest measure of material well being in the panels is a summary of total expenditures. In this 
regard there have been some positive developments. The CE has long been the main source of consumption spending in the U.S., serving the primary purpose of constructing household budget shares used in the construction of the Consumer Price Index (CPI). There has been concern raised in recent years about the CE as it continued to fall behind National Income and Product Accounts, and the BLS is actively working on a redesign of the CE (Dillman and House 2013). In addition to a potential deterioration of estimates of the CPI, the CE is used by BLS and Census to construct the poverty thresholds for the SPM, and if the CE coverage of consumption is declining over time it will introduce a new source of bias in the alternative poverty measure. Starting in 1999 the PSID expanded the set of consumption spending collected beyond food and housing to include healthcare, transportation, and other goods and services, and this data captures about 70-75 percent of nondurable spending in NIPA and has not trended downward over the decade like the CE (Blundell, Pistaferri, Saporta-Eksten 2012; Creech 2014). In addition to the PSID, starting in 2001 the HRS collected total spending and detailed subcomponents via the Consumption and Activities Mail Survey (CAMS). The MEPS has continuously collected healthcare spending throughout the panel's history, and the SIPP has collected work-related, medical, and child-care expenses in various topical modules. And in 2011 Census added questions on out-of-pocket spending on childcare and medical care to the CPS ASEC. This is to aid in the construction of the SPM, which deducts these expenditures from gross income.

Among other measures of hardship, all the panels collect information on health insurance coverage, and disability status. In the area of disability the most comprehensive treatment is found in MEPS, HRS, PSID, and SIPP. But among the more acute measures of hardshiphaving heat, air conditioning, water, or phone shut off; being evicted from a home or having the 
mortgage foreclosed; being food insecure; and facing excessive cumulative interest rates via payday lending — coverage is considerably limited. The SIPP has been the primary source for nation-wide research on material hardship as it covers many of the acute hardship measures. On the other hand, the PSID measured food insecurity in the 1999-2003 waves, and in recent waves collected information on mortgage foreclosure, but does not have other measures of acute hardship. The new ECLS-K: 2011 has added questions about foreclosure, utility disconnect, and food insecurity, but beyond these three surveys the panels are largely silent on acute material hardship.

In contradistinction, nine of the ten panels collect fairly comprehensive information on household assets, including home and auto, cash holdings, CDs, stocks, bonds, IRAs, 401Ks, real estate, and overall net worth. The exception to this is the CPS ASEC, which does not collect wealth data. The gold standard for assets in the U.S. is the SCF and all other panels are measured against it. On this score, the PSID does fairly well, followed by HRS and SIPP, over much of the distribution, but all fall short in the upper decile (Czajka, Jacobson, and Cody 2003/2004; Ratcliffe, et al. 2007; Sierminska, Michaud, and Rohwedder 2008). The NLSY79 and 97 also contain extensive wealth information. Early assessments indicated that wealth in NLSY79 fell short of the PSID and SIPP, but Zagorsky (1999) proposed a cleaned-up net asset series that replaced top coded values with original values among other fixes that resulted in a net wealth series more similar to PSID and SIPP. This breadth of wealth data across the various surveys has surprisingly been utilized much less than the income data, even though assets form the foundation of life-cycle models in the social sciences. 


\section{What Information Do We Need to Collect on Income, Program Participation, Poverty, and Financial Vulnerability?}

The United States currently collects a rich array of longitudinal data across the domains of income, poverty, program participation, and financial vulnerability. This data forms the foundation of social science research on income inequality and mobility, the dynamics of poverty and transfer program participation, and child and family well being. Returning to the questions posed in the Introduction: Is this data adequate to meet the scientific and policy needs in the coming decades? Do we need to embark in the collection of a new household panel? Or are we better served by simply improving upon what we already have in the field?

A. Data Quality and Linked Survey-Administrative Data

Nonresponse rates of earnings in excess of 30 percent in the CPS ASEC are clearly troubling and raise substantive concerns about the dataset in measuring levels and trends in poverty and inequality. These rates are ten times greater than those in the PSID, SIPP, and NLSY (Killewald, Andreski, and Schoeni 2011; Hedengren and Stratmann 2013), placing in stark relief the differences in the quality of earnings measured depending on whether the survey focus is on income. ${ }^{13}$ Moreover, the top-coding of earnings at $\$ 250,000$ in the public release version of the CPS ASEC inhibits the ability to conduct research in the upper tail of the income distribution. This concern is mitigated to some extent in the PSID and NLSY because of the much higher top codes, but here the worry is that the rich, and especially the super rich, are missing from the surveys altogether. The SCF, with the oversample of the rich and non-binding top codes, averts the problem of the missing rich, but only twice in the survey's history has a panel of two years been fielded. At the other end of the distribution, the problem is the

\footnotetext{
${ }^{13}$ Likewise earnings imputations rates in the CE are on par to those in the CPS ASEC, consistent with the CE focus on expenditures (Passero 2009).
} 
underreporting of transfers, not earnings, which jeopardizes not only our understanding of the antipoverty effectiveness of the safety net but also threatens to disrupt the flow of intergovernmental transfers owing that nearly 40 federal programs are tied to the poverty rate (Gabe 2007).

It is glib to simply exclaim “We need better data!” But in reality, we need better data. Unfortunately, embarking on a new household panel will not in and of itself solve the problem. Instead, it seems that there are two, complementary, paths going forward to improve survey collection of income data. First, adopting more uniform "best practices” for eliciting accurate income reporting across surveys would clearly be beneficial. For example, the PSID and HRS in the last decade began using EHCs for a number of domains based on evidence that this method reduces nonresponse and underreporting compared to the standard questionnaire. ${ }^{14} \mathrm{~A}$ recent experiment with EHC methods in the SIPP showed that item nonresponse in SNAP participation fell 20 percent (Kim and O’Donnell 2012). This is suggestive that the EHC may be a mechanism to shore up leakage in survey measurement of transfer income. Neither the PSID or HRS use the EHC for transfer programs, but the NLSY97 uses the related event history data method. To my knowledge there has been no analysis of how effective the NLSY97 is in collecting transfers relative to administrative aggregates along the lines performed by Meyer, Mok, and Sullivan (2009) for the ACS, CPS ASEC, SIPP, PSID, and CE. Another approach that has yielded some success in the HRS and PSID in the collection of wealth data is to use "unfolding brackets" (Heeringa, Hill, and Howell 1995; Juster, et al. 2006); that is, if the respondent cannot (or will not) report the actual dollar amount, the interviewer follows up with a series of dollar intervals that are asked in a sequential fashion. ${ }^{15}$ There is reason to believe that such an approach might

\footnotetext{
${ }^{14}$ See the review of research on the EHC approach in Fields and Callagaro (2007).

${ }^{15}$ The PSID also uses unfolding brackets in the collection of expenditure data.
} 
be useful for the collection of transfer income (and perhaps all income sources), and research is needed on this issue.

The second path to improve our household panel surveys is to expand the number of panels that link to administrative data, and to expand the number of programs that can be linked. The administrative data needed includes tax data as well as transfer program data. Linking to tax data has the potential to ameliorate three challenges facing current panel surveys: (1) income nonresponse; (2) income topcoding; and (3) income tax payments (including EITC) that are not currently collected in most panels. The clear advantage of linking to transfer program data is to address nonresponse and underreporting. There has been some progress on both of these fronts. The HRS links to both Social Security Detailed Earnings Records and to Medicare Claims data; the SIPP links to both the DER and Social Security retirement and disability data; CPS ASEC links to the DER, EITC, and 1040 files; and the PSID links to Medicare claims data. Because of the need to protect respondent confidentiality, access to these linked data are highly restricted. The applicant must demonstrate a “need to know," i.e. must write a proposal explaining how the linked data are fundamental to the project, and they must conduct the research in a secure data site. Access to the latter has improved in recent years with the expansion of Census Research Data Centers that provide secure access points, though it still can be a costly enterprise for those researchers who must travel to the sites. ${ }^{16}$ These efforts at linking to administrative data need to be expanded. With the exception of the CPS ASEC, none of the datasets currently are linked to tax return data. This has the advantage of both improved modeling of programs such as the EITC and Child Tax Credit, and more broadly to research on the incentive effects of the tax code. Efforts to link to major transfer programs such as SNAP, UI, TANF, SSI, DI, Medicaid,

\footnotetext{
${ }^{16}$ The newly released FoodAPS data produced by the USDA Economic Research Service has data linked to administrative SNAP records, access of which is gained via a "thin client" software from the researchers home location to the secure server at NORC.
} 
and Housing would offer the opportunity to better quantify the effect of transfers on the level and trend in poverty, and also provide new research into issues related to intergenerational transmission of receipt. The challenges associated with linking to admin data cannot be overstated, both legal and methodological, but they are surmountable as has been demonstrated in a few of the surveys. On the legal front, the main issue is that states administer programs like SNAP, TANF, and UI, and because there is no federal mandate to cooperate in the collection of data linking as a condition of receiving federal funds, it then becomes necessary to sign agreements with all state and tribal governments. That said, the Scandinavian countries are well ahead of the U.S. on the data-linkage front, and as such many scholars are turning to these data to conduct frontier research. We risk losing a competitive research edge if we remain on the sidelines, and importantly, will not be adequately equipped to address pressing policy issues.

\section{B. Survey Content}

Beyond data quality, there are some significant needs in terms of survey content. Given the size and growth of the program, we do not adequately collect information about disability income, especially isolating Social Security Disability Insurance from other Social Security programs or private disability insurance. Moreover, providing information on which household member is receiving assistance is needed to better model programmatic incentives and behaviors. The same is true with SSI (only the SIPP identifies the recipient, e.g. child or adult). With the exception of the SIPP, none of the panels collect dollar amounts of the EITC, and more generally, information on tax payments. Most researchers rely on the NBER TAXSIM program for tax research, and while this is a very valuable resource, it is a simulation module and therefore introduces measurement error into empirical models. 
A further challenge and need in terms of transfer program data is how we modify our surveys to acknowledge that a very large fraction of social safety net spending is in the form of in-kind transfers. For example, nearly two decades after passage of welfare reform, our ability to identify who receives assistance from TANF and how much is unknown. Most of the surveys are designed to ask for dollar amount of cash TANF, but this only captures 30 percent of total spending. By my reckoning, in the SIPP 2014 panel, TANF shows up in at least 3 separate modules, but with the exception of the questions dealing with cash assistance, one would not be able to assign the assistance to TANF because the source of help is not asked (e.g. subsidized child care). Moreover, with the rollout of the Affordable Care Act we will need to collect improved information on Medicaid, and also the value of health insurance subsidies to be used in health exchanges.

In the domain of material hardship, none of the panels collect the USDA's preferred measure of food insecurity utilizing the 18 item scale. Today 1 in 7 Americans face food insecurity and yet we are not equipped to answer questions on the long term or intergenerational consequences of this unmet food need for children and families. ${ }^{17}$ We also do an inadequate job of collecting information on measures of acute material hardship—utility shutoff, repossession, home eviction, homelessness, and debt spirals such as repeated payday loans and rent-to-own goods. With many challenging the notion that the poor in America are materially poor relative to a generation or two ago, or relative to the poor in developing nations, it will be crucial to document a number of material hardships to assess whether "possession” of the goods is a shortrun or long-run state, i.e. how much instability and inequality exists in material well being. While beyond the scope of this paper, incarceration and drug and alcohol addiction have very

\footnotetext{
${ }^{17}$ The Food and Nutrition Service in the USDA recently announced that they will fund the food security module in the PSID starting in 2015.
} 
real consequences for material well being. The NLSY is the only panel survey to collect this information, which means none of the population-wide surveys can address this wider social trend.

\section{A New Panel?}

In light of the issues of data quality and topical coverage, is it time for the U.S. to field a new panel? While the concerns with current panels are significant, my own assessment is that a higher priority is to improve upon the current panels before embarking on a completely new survey. This includes incorporating the more innovative survey methods such as EHC and unfolding brackets to elicit higher-quality responses to earnings and transfer-income questions, while simultaneously expanding the linkages to tax return (e.g. Social Security earnings and EITC) and transfer-program data (e.g. UI, SNAP, TANF). With the inclusion of consumption and health data to the PSID, consumption data to the HRS, and the redesigns of the SIPP and CE, great strides have been made over the past decade to improve the capacity to conduct social science research on poverty and inequality. I believe that these surveys will continue to serve the nation's needs well in the domain of income, poverty, and financial vulnerability.

If there is one apprehension, it is that the lone population-wide panel equipped to address issues of intergenerational mobility and dependence is the PSID. On the plus side, wave-to-wave dropout is low, data quality and topical coverage is high in general, and importantly, by 2018 the PSID will be 50 years running and in a position to examine how families are faring across three generations, and maybe four. This will continue to be a crucial data resource to learn how major changes in economic policy and family structure have affected the extended American family. On the down side, it is a heavy burden for a single dataset to shoulder, especially in light of changing demographics of the nation since the panel began in 1968. While evaluations of the 
PSID show that attrition has not had negative effects on parameter estimates of most longitudinal and intergenerational models, in its current form it will miss the demographic influx of Hispanics and Asians, who are projected to grow to 30 percent and 8 percent of the U.S. population by 2050, respectively (Ortman and Guarneri 2009). Moreover, the PSID is a comparatively small panel in terms of the number of individuals, which limits the extent of subnational analyses. Much of nonexperimental evaluation of public policies is conducted by utilizing cross-state over time variation in employment and unemployment, along with welfare/tax/criminal justice policies and programs, and the power to detect effect sizes hinges crucially on adequate sample sizes within states.

For example, consider the simple two-period difference-in-difference exercise where we are interested in using cross-state over time variation in adoption of re-employment bonuses to estimate the probability an unemployed worker returns to employment (see the Appendix for the Stata program). Assume a PSID-size sample of 23,000 individuals, which is roughly the size of the panel today, and of that 70 percent are between the ages of 16 and 65 and in the labor force. Further, let 5 percent of the labor force be unemployed, and of the unemployed, 50 percent are eligible for re-employment bonuses (this is akin to current eligibility for UI benefits). Suppose that half the states adopt the bonus policy, and this has a treatment effect size of 10 percentage points (from a re-employment probability of roughly 50 percent without treatment). The power to detect such an effect assuming a 0.05 test size and 10,000 simulations is 30 percent. Now suppose we use SIPP 2014 with roughly 35,000 households and 87,500 individuals (assuming 2.5 persons per household). The power to detect that 10 percentage point effect size is now 81 percent. Power calculations are of course sensitive to the experimental parameters of interest (e.g. power falls to 11 and 29 percent in each of the PSID and SIPP-like samples, respectively, if 
we lower the treatment effect to 5 percentage points), and thus this exercise is simply illustrative. However, it does highlight the need to keep power in mind when deliberating the prospect of a new panel.

It seems that one direction to turn is to follow the lead of the United Kingdom by combining the PSID with a new, larger nationwide panel. Specifically, in 2009 the UK folded the British Household Panel Survey (BHPS) into the wider Understanding Society panel. The BHPS was started in 1991 with 5,500 households, and eventually expanded to 10,500 households. $^{18}$ Of these, 8,000 BHPS households were invited (6,700 accepted) to join the new 40,000 household Understanding Society panel, comprised of 100,000 individuals. Both panels are managed by the Institute for Social and Economic Measurement at University of Essex. The clear advantage of retaining the BHPS in Understanding Society is both the quality and scope of the data, along with the ability to continue tracking families across a generation. An even more compelling argument can be made for retaining the PSID in a scaled-up household panel owing to its ability to span multiple generations.

A second option, and from my perspective, a preferred approach, is to continue the PSID, ideally with a refresher sample of Hispanics and Asians added in, and to launch a separate, standalone annual open-ended panel that is larger in sample size. A possible springboard for a separate panel is the redesigned SIPP with its projected sample size of about 35,000 households. Even though the panel is switching from triannual to annual interviewing, it is only scheduled to run four years from 2014 to 2018. A solution would be to follow those households and their splitoffs beyond 2018 to serve as the basis for a new long-term panel to complement the PSID. The advantage of this second approach is that it retains the integrity of the PSID design and expansive content, the latter of which might be streamlined to control costs if pooled together

\footnotetext{
${ }^{18}$ See https://www.understandingsociety.ac.uk/about/bhps-in-understanding-society for details.
} 
within a larger panel, while simultaneously improving power for nonexperimental analyses to inform present and future policy. 


\section{References}

Aaronson, Daniel, and Bhashkar Mazumder. 2008. "Intergenerational Economic Mobility in the United States, 1940 to 2000.” Journal of Human Resources 43(1): 139-172.

Abowd, John, and David Card. 1989. "On the Covariance Structure of Earnings and Hours Changes.” Econometrica 57(2): 411-445.

Altonji, Joseph, and Robert Shakotko. 1987. "Do Wages rise with Job Seniority?” Review of Economic Studies 54(3): 437-459.

Alvaredo, Facundo, Anthony Atkinson, Thomas Piketty, and Emmanuel Saez. 2013. "The Top 1 Percent in International and Historical Perspective," Journal of Economic Perspectives 27(3): 320.

Anderson, Sue Ann. 1990. "Core indicators of nutritional state for difficult-to-sample populations.” Journal of Nutrition, 120(11): 1557-1600.

Attanasio, Orazio, Erik Hurst, and Luigi Pistaferri. Forthcoming. "The evolution of income, consumption, and leisure inequality in the US, 1980-2010.” In Improving the Measurement of Consumer Expenditures, C. Carroll, T. Crossley, and J. Sabelhaus (Eds.), Boston: National Bureau of Economic Research.

Autor, David H., Lawrence F. Katz, and Melissa S. Kearney. 2008. "Trends in U.S. Wage Inequality: Re-Assessing the Revisionists.” Review of Economics and Statistics 90(2): 300-323.

Autor, David, and Mark Duggan. 2006. "The Growth in Social Security Disability Rolls: A Fiscal Crisis Unfolding.” Journal of Economic Perspectives, 20(3): 71-96.

Bailey, Martha, and Sheldon Danziger, eds. 2013. Legacies of the War on Poverty. New York: Russell Sage Foundation.

Bane, Mary Jo, and David Ellwood. 1986. "Slipping Into and Out of Poverty: The Dynamics of Spells.” Journal of Human Resources 21(1): 1-23.

Bane, Mary Jo, and David Ellwood. 1994. Welfare Realities: From Rhetoric to Reform, Cambridge, MA: Harvard University Press.

Beaule, April, Eva Leissou, and Youhong Lui. 2007. "Experiences Using and Event History Calendar in the Panel Study of Income Dynamics.” PSID Technical Series Paper \#07-02.

Blank, Rebecca. 2009. “What We Know, What We Don't Know, and What We Need to Know about Welfare Reform.” In Welfare Reform and its Long Term Consequences for America's Poor, (J. Ziliak, ed.), Cambridge, UK: Cambridge University Press, 22-58. 
Blank, Rebecca and Brian Kovak. 2008. "Helping Disconnected Single Mothers.” Center on Children and Families Brief \#38, Washington, DC: The Brookings Institution.

Blank, Rebecca, and Patricia Ruggles. 1993. "When Do Women Use AFDC \& Food Stamps?

The Dynamics of Eligibility vs. Participation.” Journal of Human Resources 31(1): 57-89.

Blundell, Richard. Forthcoming. "Income Dynamics and Life-Cycle Inequality: Mechanisms and Controversies.” Economic Journal.

Blundell, Richard, and Luigi Pistaferri. 2003. "Income Volatility and Household Consumption: The Impact of Food Assistance Programs.” Journal of Human Resources 38(Supplement): 10321050.

Blundell, Richard, Luigi Pistaferri, and Ian Preston. 2008. “Consumption Inequality and Partial Insurance.” American Economic Review 98(5): 1887-1921.

Blundell, Richard, Luigi Pistaferri, and Itay Saporta-Eksten. 2012. “Consumption Inequality and Family Labor Supply.” NBER Working Paper 2012.

Bollinger, Christopher and Barry Hirsch. 2006. "Match Bias from Earnings Imputation in the Current Population Survey: The Case of Imperfect Matching.” Journal of Labor Economics, 24(3): 483-519.

Bollinger, Christopher and Barry Hirsch. 2013. “Is Earnings Nonresponse Ignorable?” Review of Economics and Statistics, 95(2): 407-416.

Bollinger, Christopher, Barry Hirsch, Charles Hokayem, and James P. Ziliak. 2014. "Earnings Nonresponse and Earnings Inequality.” Presentation at the Federal Reserve Bank of Cleveland, March 1, 2014.

Bound, John, and Alan Krueger. 1991. “The Extent of Measurement Error in Longitudinal Earnings Data: Do Two Wrongs Make a Right?” Journal of Labor Economics 9(1): 1-24.

Bound, John, Charles Brown, and Nancy Mathiowetz. 2001. "Measurement Error in Survey Data.” In Handbook of Econometrics, Volume 5, J. Heckman and E. Leamer (eds.), Amsterdam: North Holland.

Bourguignon, Francois, Satya Chakravarty. 2003. "The Measurement of Multidimensional Poverty." Journal of Economic Inequality 1(1): 25-49.

Brown, Charles. 1980. “Equalizing Differences in the Labor Market.” Quarterly Journal of Economics 94(1): 113-134.

Burkhauser, Richard, Shuaizhang Feng, Stephen P. Jenkins, and Jeff Larrimore. 2012. "Recent Trends in Top Income Shares in the USA: Reconciling Estimates from March CPS and IRS Tax Return Data.” The Review of Economics and Statistics 94(2): 371-388. 
Card, David. 1986. "The Effect of Unions on the Structure of Wages: A Longitudinal Analysis.” Econometrica 64(4): 957-979.

Chamberlain, Gary. 1978. "Omitted Variable Bias in Panel Data: Estimating the Returns to Schooling.” Annales de l'inséé 30/31(49-82).

Chetty, Raj, Nathaniel Hendren, Patrick Kline, and Emmanuel Saez. 2014. "Where is the Land of Opportunity? The Geography of Intergenerational Mobility in the United States.” NBER Working Paper 19843.

Chetty, Raj, Nathaniel Hendren, Patrick Kline, Emmanuel Saez, Nicholas Turner. 2014. "Is the United States Still a Land of Opportunity? Recent Trends in Intergenerational Mobility.” NBER Working Paper 19844.

Citro, Constance, and Robert Michael, eds. 1995. Measuring Poverty: A New Approach. Washington: National Academy Press.

Cochrane, John. 1991. “A Simple Test of Consumption Insurance.” Journal of Political Economy 99(5): 957-976.

Corak, Miles. 2013. "Income Inequality, Equality of Opportunity, and Intergenerational Mobility.” Journal of Economic Perspectives 27(3): 79-102.

Council of Economic Advisers. 2014. The War on Poverty 50 Years Later: A Progress Report. Executive Office of the President of the United States.

Creech, Brett. 2014. "A Comparison of Consumer Expenditure Survey and Panel Study of Income Dynamics Expenditure Data: 1999-2009.” Bureau of Labor Statistics Discussion Paper.

Czajka, John, Jonathan Jacobson, and Scott Cody. 2003/2004. "Survey Estimates of Wealth: A Comparative Analysis and Review of the Survey of Income and Program Participation." Social Security Bulletin 65(1): 63-69.

Currie, Janet. 2003. “U.S. Food and Nutrition Programs.” In Means-Tested Transfer Programs in the United States, R. Moffitt (ed.), Chicago: University of Chicago Press, 199-290.

Dahl, Gordon, Andreas Kostol, and Magne Mogstad. 2013. “Family Welfare Cultures.” Mimeo.

Dahl, Molly, Thomas DeLeire, and Jonathan Schwabish. 2011. "Estimates of Year-to-Year Variability in Worker Earnings and in Household Incomes from Administrative, Survey, and Matched Data.” Journal of Human Resources 46(4): 750-774.

Dillman, Don, and Carol House. 2013. Measuring What We Spend: Toward a New Consumer Expenditure Survey. National Research Council, Committee on National Statistics, Washington, DC: The National Academies Press. 
Duncan, Greg, and Jeanne Brooks-Gunn. 1999. Consequences of Growing Up Poor. New York: Russell Sage Foundation.

Duncan, Greg, Martha Hill, and Saul Hoffman. 1988. "Welfare Dependence within and across Generations.” Science 239(4839): 467-471.

Durlauf, Steven. 2012. “Poverty Traps and Appalachia,” in Appalachian Legacy: Economic Opportunity after the War on Poverty. James P. Ziliak (ed.), Washington, DC: Brookings Institution Press, 169-206.

Dynan, Karen, Douglas Elmendorf, and Daniel Sichel. 2012. “The Evolution of Household Income Volatility.” The B.E. Journal of Economic Analysis \& Policy: Advances, Volume 12, Issue 2: Article 3.

Dynarski, Susan, and Jonathan Gruber. 1997. “Can Families Smooth Variable Earnings?” Brookings Papers on Economic Activity 1: 229-284.

Edin, Kathryn, and Laura Lein. 1997. Making Ends Meet: How Single Mothers Survive Welfare and Low-Wage Work. New York: Russell Sage Foundation.

Fields, Jason, and Mario Callegaro. 2007. "Background and Planning for Incorporating an Event History Calendar into the Re-Engineered SIPP.” Presented at the 2007 Federal Committee on Statistical Methodology Research Conference.

Fitzgerald, John. 2011. "Attrition in Models of Intergenerational Links using the PSID with Extensions to Health and to Siblings Models.” The B.E. Journal of Economic Analysis \& Policy 11(3): vol11/iss3/art2/.

Fitzgerald, John, Peter Gottschalk, and Robert Moffitt. 1998. “An Analysis of the Impact of Sample Attrition on the Second Generation of Respondents in the Michigan Panel Study of Income Dynamics.” Journal of Human Resources 33(2): 300-344.

Frankel, Martin, Harold McWilliams, and Bruce Spencer. 1983. National Longitudinal Survey of Labor Force Behavior, Youth Survey: Technical Sampling Report.

Freeman, Richard. 1984. “Longitudinal Analyses of the Effects of Trade Unions.” Journal of Labor Economics 2(1):1-26.

Gabe, Thomas. 2007. "Federal Programs that Use the "Official” Poverty Definition for Determining Eligibility or for Allocating Funds,” Memo from the Congressional Research Service to the U.S. House Ways and Means Subcommittee on Income Security and Family Support (October 30).

Ganong, Peter, and Jeffrey Liebman. 2013. “Explaining Trends in SNAP Enrollment,” Mimeo, 
Harvard University.

Garces, Eliana, Duncan Thomas, and Janet Currie. 2002. "Longer Term Effects of Head Start.” American Economic Review 92(4): 999-1012.

Gennetian, Lisa, Jens Ludwig, Thomas McDade, and Lisa Sanbonmatsu. 2013. "Why Concentrated Poverty Matters.” Pathways: A Magazine on Poverty, Inequality, and Social Policy, Spring 2013, 9-13.

Gittleman, Maury. 2001. "Declining Caseloads: What Do the Dynamics of Welfare Participation Reveal?” Industrial Relations 40(4): 537-570.

Gottschalk, Peter. 1990. “AFDC Participation across Generations.” American Economic Review 80(2): 367-371.

Gottschalk, Peter, and Robert Moffitt. 1994. "The Growth of Earnings Instability in the U.S. Labor Market.” Brookings Papers on Economic Activity 2: 217-272.

Gottschalk, Peter, and Robert Moffitt. 2012. "Trends in the Transitory Variance of Male Earnings, 1970-2004.” Journal of Human Resources 47(1): 204-236.

Greenwood, Jeremy, Nezih Guner, Georgi Kocharkov, and Cezar Santos. 2014. "Marry Your Like: Assortative Mating and Income Inequality.” NBER Working Paper 19829.

Griliches, Zvi, and Jerry Hausman. 1986. "Errors in Variables in Panel Data.” Journal of Econometrics 31(1): 93-118.

Groves, Robert. 2001. Survey Nonresponse. New York: Wiley.

Grusky, David, and Erin Cumberworth. 2010. “A National Protocol for Measuring Intergenerational Mobility?” Stanford Center on Poverty and Inequality.

Gundersen, Craig, Brent Kreider, and John Pepper. 2011. "The economics of food insecurity in the United States.” Applied Economic Perspectives and Policy 33(3):281-303.

Gundersen, Craig, and James P. Ziliak. 2003. "The Role of Food Stamps in Consumption Stabilization.” Journal of Human Resources 38(Supplement): 1051-1079.

Hacker, Jacob. 2006. The Great Risk Shift. Oxford, UK: Oxford University Press.

Haider, Steven. 2001. "Earnings Instability and Earnings Inequality of Males in the United States: 1967-1991.” Journal of Labor Economics 19(4): 799-836.

Hall, Robert, and Frederic Mishkin. 1982. "The Sensitivity of Consumption to Transitory Income: Estimates from Panel Data on Households.” Econometrica 50(2): 461-481. 
Hardy, Bradley. Forthcoming. "Childhood Income Volatility and Adult Outcomes.” Demography.

Hardy, Bradley, and James P. Ziliak. 2014. "Decomposing Trends in Income Volatility: The 'Wild Ride' at the Top and Bottom.” Economic Inquiry 52(1): 459-476.

Hausman, Jerry, and William Taylor. 1981. "Panel Data and Unobservable Individual Effects." Econometrica 49(6): 1377-1398.

Haveman, Robert, Sheldon Danziger, and Robert Plotnick. 1981. "How Income Transfers Affect Work, Savings, and the Income Distribution.” Journal of Economic Literature 19(3): 975-1028.

Hayashi, Fumio, Joseph Altonji, and Laurence Kotlikoff. 1996. "Risk-Sharing Between and Within Families.” Econometrica 64(2): 261-294.

Heckman, James, Hidehiko Ichimura, and Petra Todd. 1997. "Matching as an Econometric Evaluation Estimator: Evidence from Evluating a Job Training Programme.” Review of Economic Studies 64(4): 605-654.

Heckman, James J., Jora Stixrud and Sergio Urzua. 2006. “The Effects of Cognitive and Noncognitive Abilities on Labor Market Outcomes and Social Behavior," Journal of Labor Economics 24(3): 411-482.

Hedengren, David, and Thomas Stratmann. 2013. “The Dog the Didn’t Bark: Item NonResponse Effects on Earnings and Health.” George Mason University, Mimeo.

Heeringa, Steven, Daniel Hill, and David Howell. 1995; "Unfolding Brackets for Reducing Item Nonresponse in Economic Surveys.” PSID Technical Series Paper \#95-01.

Heflin, Colleen. 2014. "Household Instability and Material Hardship.” Presentation at the University of Michigan Conference on Poverty, Policy, and People: 25 Years of Research and Training at the University of Michigan.

Heflin, Colleen, and J.S. Butler. 2013. "Why Do Women Enter and Exit from Material Hardship?” Journal of Family Issues, 34(5): 631-660.

Hill, Martha. 1992. The Panel Study of Income Dynamics: A User's Guide. Newbury Park, CA: Sage Publications, Inc.

Hirsch, Barry and Edward Schumacher. 2004. "Match Bias in Wage Gap Estimates Due to Earnings Imputation.” Journal of Labor Economics, 22(3), pp. 689-722.

Hokayem, Charles, Christopher Bollinger, and James P. Ziliak. 2014. "The Role of CPS Nonresponse on the Level and Trend in Poverty.” University of Kentucky Center for Poverty Research Discussion Paper 2014-05. 
Holtz-Eakin, Douglas, Whitney Newey, and Harvey Rosen. 1988. "Estimating Vector Autoregressions with Panel Data.” Econometrica 56(6): 1371-1395.

Hotz, V. Joseph, and John Karl Scholz. 2003. “The Earned Income Tax Credit.” In Means-Tested Transfer Programs in the United States, R. Moffitt (ed.), Chicago: University of Chicago Press, 141-198.

House Budget Committee. 2014. The War on Poverty: 50 Years Later. Committee on the Budget: U.S. House of Representatives.

Hoynes, Hilary. 2000. "Local Labor Markets and Welfare Spells: Do Demand Conditions Matter?” Review of Economics and Statistics 82(3): 351-368.

Hoynes, Hilary, Diane Schanzenbach, and Douglas Almond. 2013. “Long Run Impacts of Childhood Access to the Safety Net.” Mimeo.

Hutchens, Robert. 1981. "Entry and Exit Transitions in a Government Transfer Program: The Case of Aid to Families with Dependent Children.” Journal of Human Resources 16(2): 217237.

Jargowsky, Paul. 1997. Poverty and Place: Ghettos, Barrios, and the American City. New York: Russell Sage Foundation.

Johnson-Herring, Sylvia, and Sharon Krieger. 2008. "Response Rates in the Consumer Expenditure Survey.” Consumer Expenditure Survey Anthology.

Juster, F. Thomas, Honggao Cao, Michael Perry, and Mick Couper. 2006. “The Effect of Unfolding Brackets on the Quality of Wealth Data in HRS.” University of Michigan Retirement Research Center Working Paper 2006-113.

Kasprzyk, Daniel, Greg Duncan, Graham Kalton, and M.P. Singh (eds.). 1989. Panel Surveys. Wiley Series in Probability and Statistics, New York: Wiley.

Katz, Lawrence, and Bruce Meyer. 1990. “The Impact of Potential Duration of Unemployment Benefits on the Duration of Unemployment.” Journal of Public Economics 41(1): 45-72.

Katz, Lawrence, and David Autor. 1999. "Changes in the Wage Structure and Earnings Inequality,” in Handbook of Labor Economics, Orley Ashenfelter and David Card, eds., Amsterdam: Elsevier.

Keane, Michael, and Robert Moffitt. 1998. “A Structural Model of Multiple Welfare Program Participation and Labor Supply.” International Economic Review 39(3): 553-589.

Keane, Michael and Kenneth Wolpin. 1997. “The Career Decisions of Young Men.” Journal of Political Economy 105(3): 473-522. 
Kenworthy, Lane. 2013. “Has Rising Inequality Reduced Middle-Class Income Growth?” In Income Inequality: Economic Disparities and the Middle Class in Affluent Countries, Janet C. Gornick and Markus Jäntti (eds.), Palo Alto: Stanford University Press, 101-114.

Keys, Ben. 2008. “Trends in Income and Consumption Volatility, 1970-2000.” In Income Volatility and Food Assistance in the United States, D. Jolliffe and J. P. Ziliak, eds., Kalamazoo, MI: W.E. Upjohn Institute.

Killewald, Alexandra, Patricia Andreski, and Robert Schoeni. 2011. “Trends in Item NonResponse in the PSID, 1968-2009.” PSID Technical Series Paper \#11-02.

Kim, Jeongsoo, and Sharon O’Donnell. 2012. "Comparing Item Nonresponse Rate in SIPP and SIPP-EHC: Case of SNAP Eligibility Measurement.” Presented at the American Statistical Association Joint Statistical Meetings, San Diego, CA.

Kneebone, Elizabeth, Carey Nadeau, and Alan Berube. 2011. “The Re-Emergence of Concentrated Poverty: Metropolitan Trends in the 2000s.” Metropolitan Opportunity Series, Brookings Institution, Washington, DC.

Kniesner, Thomas J., W. Kip Viscusi, Christopher Woock, and James P. Ziliak. 2012. “The Value of a Statistical Life: Evidence from Panel Data.” The Review of Economics and Statistics 94(1): 74-87.

Kniesner, Thomas J., and James P. Ziliak. “Tax Reform and Automatic Stabilization.” American Economic Review 92(3): 590-612.

Kristof, Nicholas. 2012. "Profiting from a Child’s Illiteracy.” The New York Times. December 7, SR1.

Krueger, Alan, and Lawrence Summers. 1988. "Efficiency Wages and the Inter-Industry Wage Structure.” Econometrica 56(2):259-93.

Lalonde, Robert. 1986. "Evaluating the Econometric Evaluations of Training Programs with Experimental Data.” American Economic Review 76(4): 604-620.

Lawrance, Emily. 1991. "Poverty and the Rate of Time Preference.” Journal of Political Economy 99(1): 54-77.

Lee, Chul-In, and Gary Solon. 2009. "Trends in Intergenerational Income Mobility.” The Review of Economics and Statistics 91(4): 766-772.

Lemieux, Thomas. 2006. "Increasing Residual Wage Inequality: Composition effects, Noisy Data, or Rising Demand for Skill?” American Economic Review 96(3): 461-498.

Levy, Helen. 2009. "Income, Material Hardship, and the Use of Public Programs among the Elderly.” University of Michigan Retirement Research Center Working Paper 2009-208. 
Lillard, Lee, and Constantijn Panis. 1998. "Panel Attrition from the Panel Study of Income Dynamics: Household Income, Marital Status, and Mortality.” Journal of Human Resources 33(2): 437-457.

Lillard, Lee, and Robert Willis. 1978. “Dynamic Aspects of Earnings Mobility.” Econometrica 46(5): 985-1012.

Lowrey, Annie. 2014. “50 Years Later, War on Poverty is a Mixed Bag.” New York Times, January 4. p. A1.

MaCurdy, Thomas. 1981. "An Empirical Model of Labor Supply in a Life Cycle Setting.” Journal of Political Economy 89, 1059-85.

MaCurdy, Thomas. 1982. "The Use of Time Series Processes to Model the Error Structure of Earnings in a Longitudinal Data Analysis.” Journal of Econometrics 18(1): 83-114.

MaCurdy, Thomas, Thomas Mroz, and R. Mark Gritz. 1998. "An Evaluation of the National Longitudinal Survey on Youth.” Journal of Human Resources 33(2): 345-436.

Mayer, Susan, and Christopher Jencks. 1989. "Poverty and the Distribution of Material Hardship.” Journal of Human Resources 24(1): 88-114.

McLanahan, Sara, and Gary Sandefur. 1994. Growing Up With a Single Parent. Cambridge, UK: Cambridge University Press.

Meghir, Costas, and Luigi Pistaferri. 2004. “Income Variance Dynamics and Heterogeneity.” Econometrica 72(1): 1-32.

Meyer, Bruce, and Dan Rosenbaum. 2001. "Welfare, the Earned Income Tax Credit, and the Labor Supply of Single Mothers.” Quarterly Journal of Economics 116( 3): 1063-1114.

Meyer, Bruce, and James Sullivan. 2012. "Winning the War: Poverty from the Great Society to the Great Recession.” Brookings Papers on Economic Activity 45(2): 133200.

Meyer, Bruce, Wallace Mok, and James Sullivan. 2009. “The Under-Reporting of Transfers in Household Surveys: Its Nature and Consequences.” NBER Working Paper 15181.

Moffitt, Robert. 1992. "Incentive Effects of the U.S. Welfare System.” Journal of Economic Literature 30(1): 1-61.

Moffitt, Robert, ed. 2003. “The Temporary Assistance for Needy Families Program” In MeansTested Transfer Programs in the United States, R. Moffitt (ed.), Chicago: University of Chicago Press, 291-364. 
Moffitt, Robert. 2004. "Policy Interventions, Low-Level Equilibria, and Social Interactions.” In Social Dynamics, Steven Durlauf and H. Peyton Young (eds.), Cambridge, MA: The MIT Press, 45-82.

Moffitt, Robert. 2014. "Multiple Program Participation and the SNAP Program.” University of Kentucky Center for Poverty Research Discussion Paper 2014-04.

Moffitt, Robert, and John Karl Scholz. 2010. “Trends in the Level and Distribution of Income Support.” In Tax Policy and the Economy, J. Brown (ed.), 111-152.

Ortman, Jennifer, and Christine Guarneri. 2009. "United States Population Projections: 2000 to 2050.” U.S. Census Bureau.

Page, Marianne. 2004. "New Evidence on Intergenerational Correlations in Welfare Participation.” in Generational Income Mobility in North America and Europe, Miles Corak, Editor, Cambridge, UK: Cambridge University Press.

Parker, Jonathan A., and Annette Vissing-Jorgensen. 2010. “The Increase in Income Cyclicality of High-Income Households and its Relation to the Rise in Top Income Shares.” Brookings Papers on Economic Activity 41(2): 1-55.

Passero, Bill. 2009. "The Impact of Income Imputation in the Consumer Expenditure Survey.” Monthly Labor Review, August, 25-42.

Pepper, John. 2000. “The Intergenerational Transmission of Welfare Receipt: A Nonparametric Bounds Analysis,” The Review of Economics and Statistics 82(3): 472-88.

Pierret, Charles, Alison Aughingaugh, A. Rupa Datta, and Tricia Gladden. 2007. "Event History Data: Lessons from the NLSY97.” Presented at the Conference in the Event History Calendar Method, Washington, D.C.

Piketty, Thomas. 2014. Capital in the Twenty-First Century. Cambridge, MA: Belnap Press.

Piketty, Thomas, and Emmanuel Saez. 2003. "Income Inequality in the United States, 19131998.” Quarterly Journal of Economics 118(1): 1-39.

Ratcliffe, Caroline, Henry Chen, Trina Shanks, Yunju Nam, Mark Schreiner, Min Zhan, and Michael Sherraden. 2007. "Assessing Asset Data on Low-Income Households: Current Availability and Options for Improvement.” Report to the U.S. Department of Health and Human Services, The Urban Institute.

Rector, Robert. 2007. "How Poor are America’s Poor? Examining the "Plague” of Poverty in America.” Backgrounder, No. 2064, The Heritage Foundation.

Sawhill, Isabel. 1988. "Poverty in the U.S.: Why is it so Persistent?” Journal of Economic Literature 26(3): 1073-1119. 
Schoeni, Robert, Frank Stafford, Katherine McGonagle, and Patricia Andreski. "Response Rates in National Panel Surveys." Annals of the American Academy of Political and Social Science 645(1): 60-87.

Sen, Amartya. 1993. “Capability and Well Being.” In Quality of Life, M. Nussbaum and A. Sen (eds.), Oxford, UK: Clarendon Press, 30-53.

Shaefer, H. Luke, and Kathryn Edin. 2013. "Rising Extreme Poverty in the United States and the Response of Federal Means-Tested Transfer Programs.” Social Service Review 8(2):250-268.

Short, Kathleen. 2013. “The Research Supplemental Poverty Measure: 2012.” U.S. Census Bureau, Current Population Reports, P60-247.

Siebens, Julie. 2013. "Extended Measures of Well-Being: Living Conditions in the United States: 2011.” U.S. Census Bureau, Household Economic Studies, P70-136.

Sierminska, Eva, Pierre-Carl Michaud, and Susann Rohwedder. 2008. "Meauring Wealth Holdings of Older Americans in the U.S.: A Comparison using the HRS, PSID, and SCF." Mimeo.

Smeeding, Timothy. 1982. "Alternative Methods for Valuing Selected In-Kind Transfer Benefits and Measuring Their Effect on Poverty.” U.S. Department of Commerce, Bureau of Census, Technical Paper 50.

Solon, Gary. 1992. "Intergenerational Income Mobility in the United States.” The American Economic Review 82(3): 393-408.

Stevens, Ann Huff. 1999. "Climbing Out of Poverty, Falling Back In: Measuring the Persistence of Poverty over Multiple Spells.” Journal of Human Resources 34(3): 557-588.

Stiglitz, Joseph, Amerya Sen, and Jean-Paul Fitoussi. 2009. Report by the Commission on the Measurement of Economic Performance and Social Progress.

U.S. Census Bureau. 2011. "An Initial Evaluation of the 2010 Field Test of the Re-Engineered SIPP.” SIPP-EHC Data Evaluation Workgroup.

Venkatesh, Sudhir. 2006. Off the Books: The Underground Economy of the Urban Poor. Cambridge, MA: Harvard University Press.

Weeden, Kim, and David Grusky. 2012. "The Three Worlds of Inequality.” American Journal of Sociology 117(6): 1723-1785.

Weinberg, Daniel. 1985. “Filling the 'Poverty Gap’: Multiple Transfer Program Participation.” Journal of Human Resources 20 (1): 64-89. 
Western, Bruce. 2007. Punishment and Inequality in America. New York: Russell Sage Foundation.

Western, Bruce, and Jake Rosenfeld. 2011. "Unions, Norms, and the Rise of U.S. Wage Inequality.” American Sociological Review 76(4): 513-537.

Wheaton, Laura. (2007). "Underreporting of Means-Tested Transfer Programs in the CPS and SIPP,” 2007 Proceedings of the American Statistical Association, Social Statistics Section, Alexandria, VA: American Statistical Association: 3622-3629.

Wilson, William Julius. 1987. The Truly Disadvantaged: The Inner City, the Underclass, and Public Policy. Chicago, IL: University of Chicago Press.

Wimer, Christopher, Liana Fox, Irv Garfinkel, Neeraj Kaushal, and Jane Waldfogel. 2013. “Trends in Poverty with an Anchored Supplemental Poverty Measure.” Institute for Research on Poverty, University of Wisconsin, Discussion Paper 1416-13.

Zabel, Jeffrey. 1998. “An Analysis of Attrition in the Panel Study of Income Dynamics and the Survey of Income and Program Participation with an Application to a Model of Labor Market Behavior.” Journal of Human Resources 33(2): 479-506.

Zagorsky, Jay. 1999. “Young Baby Boomers’ Wealth.” Review of Income and Wealth 45(2):435456.

Zeldes, Stephen P. 1989. "Consumption and Liquidity Constraints: An Empirical Investigation,” Journal of Political Economy 97(2): 305-346.

Ziliak, James P. 2006. "Understanding Poverty Rates and Gaps: Concepts, Trends, and Challenges,” Foundations and Trends in Microeconomics, 1(3): 127-199.

Ziliak, James P. 2011. "Recent Developments in Antipoverty Policies in the United States.” University of Kentucky Center for Poverty Research Discussion Paper 2011-05.

Ziliak, James P., ed. 2012. Appalachian Legacy: Economic Opportunity after the War on Poverty. Washington, DC: Brookings Institution Press.

Ziliak, James P. 2013. "Why Are So Many Americans on Food Stamps? The Role of the Economy, Policy, and Demographics.” University of Kentucky Center for Poverty Research Discussion Paper 2013-01.

Ziliak, James P, Bradley Hardy, and Christopher Bollinger. 2011. "Earnings Volatility in America: Evidence from Matched CPS.” Labour Economics, 18(6): 742-754.

Ziliak, James P., and Thomas J. Kniesner. 1998. "The Importance of Sample Attrition in Life Cycle Labor Supply Estimation.” Journal of Human Resources 33(2): 507-530. 


\section{Appendix: Simulation Program to Compute Power}

Note: This program was written by Lewis Warren to simulate power in the context of a twoperiod panel data setting with no attrition. It is provided to the user community for replication and extension to other setting. Please acknowledge Lewis Warren and University of Kentucky Center for Poverty Research. All risk lies with the user.

** Computes Power for a Simulated Re-Employment Bonus Program for Unemployed Workers

clear

program drop_all

program PANELPOWER, rclass

drop_all

** For Below:

** Approximately 9,000 families in PSID

** Avg. Family has 2.55 persons, so approximately 23,000 individuals

** Assume that policy is only for unemployed workers age 16-65. Assume that 70\% of sample is between 16-65 and in labor force

** Treatment group is Unemployed which we assume is $5 \%$ of total working age population.

**Treatment is a re-employment bonus. If untreated, re-employment probability is just over $50 \%$

** Assume $50 \%$ of Unemployed are not eligible for treatment even if live in eligible state (this could be like not being eligible for a program such as UI)

** Observe for 2 Periods

** Percentage of states offering Treatment is 50 percent

global I=23000 /* Number of Individuals in Sample */

global A=.70 $\quad / *$ Percentage of Sample Aged 16-65 and in Labor Force */

global $\mathrm{U}=.05 \quad / *$ Percentage of Labor Force that is Unemployed */

global E $=.50 \quad / *$ Percentage Eligible for Treatment */

global $\mathrm{T}=2 \quad / *$ Observe for 2 Periods */

global S=.5 $\quad / *$ Percentage of States Offering Treatment */

global $\mathrm{J}=.1 \quad / *$ Treatment Effect Size */

global $\mathrm{G}=0 \quad / *$ Test if effect is different from this value */

** Number of Observations

global $\mathrm{N}=\operatorname{round}(\$ \mathrm{I} * \$ \mathrm{~A} * \$ \mathrm{U} * \$ \mathrm{E} * \$ \mathrm{~T}, 2)$

set obs $\$ \mathrm{~N}$

gen $n=\_n$

gen Person_ID = round(n,\$T)

replace Person_ID = Person_ID/\$T

sort Person_ID

by Person_ID: gen $t=\_n$ 
** Generate Period

gen Period $=$.

replace Period $=\mathrm{t}$

replace Period $=($ Period -1$)$

** Generate Treated

gen Treated $=1$

replace Treated $=0$ if Person_ID $<=(1-\$ S) *(\$ N / 2)$

gen $\mathrm{TxP}=$ Treated $*$ Period

gen $\mathrm{x} 1=\operatorname{rchi} 2(1)+3$

gen $x 2=\operatorname{rbeta}(1,2)+2$

gen $\mathrm{y}=$ runiform()

replace $\mathrm{y}=(\mathrm{y}+\$ \mathrm{~J})$ if $\mathrm{TxP}==1$

replace $\mathrm{y}=(\mathrm{y}+.05 * \ln (\mathrm{x} 1))$

gen ReEmployed $=\operatorname{round}(\mathrm{y}, 1)$

*replace ReEmployed $=$

reg ReEmployed Period Treated TxP x1 x2, cluster(Person_ID)

return scalar $\mathrm{b}=\_\mathrm{b}[\mathrm{TxP}]$

return scalar se $=\_$se $[\mathrm{TxP}]$

test $\mathrm{TxP}=\$ \mathrm{G}$

return scalar $r=(r(p)<.05)$

end

simulate b_SIM=r(b) se_SIM=r(se) Power=r(r), reps(10000) nolegend nodots: PANELPOWER mean b_SIM se_SIM Power 